PATRICIA STELLA SILVA SAMPAIO

CUIDADO DA FAMÍLIA EM PEDIATRIA: VIVÊNCIA DO

ENFERMEIRO EM UM HOSPITAL UNIVERSITÁRIO

SÃOPAULO

2011 


\title{
CUIDADO DA FAMÍLIA EM PEDIATRIA: VIVÊNCIA DO ENFERMEIRO EM UM HOSPITAL UNIVERSITÁRIO
}

\author{
Dissertação apresentada à Escola de \\ Enfermagem da Universidade de São \\ Paulo para obtenção do título de Mestre \\ em Ciências \\ Área de Concentração: Cuidado em Saúde \\ Orientadora: Prof. ${ }^{a}$ Dr. ${ }^{a}$ Margareth Angelo
}

SÃOPAULO

2011 


\section{AUTORIZO A REPRODUÇÃO E DIVULGAÇÃO TOTAL OU PARCIAL DESTE TRABALHO, POR QUALQUER MEIO CONVENCIONAL OU ELETRÔNICO, PARA FINS DE ESTUDO E PESQUISA, DESDE QUE CITADA A FONTE.}

Assinatura:

Data:

Sampaio, Patrícia Stella Silva

Cuidado da família em pediatria: vivência do enfermeiro em um hospital universitário / Patrícia Stella Silva Sampaio. -São Paulo, 2011.

$101 \mathrm{p}$.

Dissertação (Mestrado) - Escola de Enfermagem da Universidade de São Paulo.

Orientadora: $\operatorname{Prof}^{\mathrm{a}} \mathrm{Dr}^{\mathrm{a}}$ Margareth Angelo

1. Enfermagem da família 2. Enfermagem pediátrica 3. Fenomenologia 4. Cuidado centrado na família 5. Família I. Título. 
NOME: PATRICIA STELLA SILVA SAMPAIO

TíTULO: Cuidado da família em pediatria: vivência do enfermeiro em um hospital universitário

Dissertação apresentada à Escola de Enfermagem da Universidade de São Paulo para obtenção do título de Mestre em Ciências

Aprovado em:

BANCA EXAMINADORA

Prof. Dr.

Instituição:

Julgamento

Assinatura:

Prof. Dr.

Instituição:

Julgamento

Assinatura:

Prof. Dr.

Instituição:

Julgamento

Assinatura:

Prof. Dr.

Instituição:

Julgamento

Assinatura: 


\section{DEDICATÓRIA}

Dedico este trabalho à $\mathcal{D E U S}$ que na sua bondade de Pai abriu as águas, me ensinou a andar e trouxe o Impossivel para que o meu viver se tornasse mais que possivel; à minha avó Ana, minha mãe e às minhas fithas Ingride Jessica pela cumplicidade que nos fortalece a cada desafio: Como Amo Vocês!!! 


\section{AGRADECISENTOS}

Meus sinceros agradecimentos a: Prof. ${ }^{a}$ Dr. ${ }^{a}$ Margareth Angelo pela atenção, por ter acreditado $e$ proporcionado condições para o desenvolvimento deste trabalho, Prof. ${ }^{a}$ Dr. ${ }^{a}$ Miriam Aparecida Barbosa Merighi pelo zelo e cuidado na transmissão do conhecimento,

Prof. ${ }^{a}$ Dr. ${ }^{a}$ Cecília Helena de Siqueira Sigaud pelo acolfimento, disponibilidade e confiança a mim dispensados,

As queridas prof. as Lisabelle, Elaine e Regina por estarem ao meu lado, por acolherem as situações adversas paralelas e me ajudarem a ter uma perspectiva diferente. Vocês são muito especiais para mim, Aos irmãos em Cristo da IBFH, por me ensinarem o significado da palavra AMOR na ótica cristã,

Às companheiras de jornada Claudia, Andréia Cascaes (Dé),Juliana, Patricia Freitas, Cris Pauli, Caroll, Maira, Simone, por tudo o que vivemos e nos tornams: 
Às minhas amigas Taty, Dany e Sandrinha que sempre estiveram ao junto a mim, e que apesar da distância fazem parte do meu dia a dia, A todos do dept. ENNP, pela ajuda, pelo acolfimento, pelas palavras de carinho e motivação, pela paciência,

Ao Marcello, por ter formatado com tanto esmero esse trabalho,

Ao Centro Universitário São Camilo, por ter me proporcionado a primeira experiência como docente,

A minha amiga Júlia Teixeira Nicolosi, sem a qual esse sonho não teria se tornado realidade, O meu muito obrigada!!! 


\section{AGRADECIMENTO ESPECIAL,}

Aos meus irmões Júnior e Léo, pelo que vocês representam na minha vida,

A todas as familias que tive o privilégio de conviver durante exercicio profissional,

Ao meu "Pequeno Príncipe" Gabriele sua família que me mostram na prática o quão maravilhoso é caminhar junto com vocês,

Às minha colegas enfermeiras por partilharem comigo o cotidiano profissional. 
Eu descobri um paradoxo. Se você amar até doer, não vai haver mais dor, apenas mais AMOR.

Madre Tereza de Calcutá 
Sampaio PSS. Cuidado da família em pediatria: vivência do enfermeiro em um hospital universitário [Dissertação]. São Paulo (SP): Escola de Enfermagem, Universidade de São Paulo; 2011.

\section{RESUMO}

O propósito da pesquisa foi desvelar o fenômeno: a enfermeira no cuidado à família da criança hospitalizada. Este estudo de natureza qualitativa teve como objetivos: conhecer a vivência do enfermeiro no cuidado às famílias de crianças hospitalizadas em unidades pediátricas e apreender o típico da vivência dos enfermeiros em ações que envolvem este cuidado. Foi utilizado como referencial teórico filosófico a abordagem da Fenomenologia Social de Alfred Schütz. Foram realizadas entrevistas com 16 enfermeiras que atuavam em unidades de emergência pediátricas, terapia intensiva pediátrica e neonatal, berçário e unidade de internação de um hospital universitário da cidade de São Paulo, tendo como foco sua vivência no cuidado às familias de crianças hospitalizadas. A análise conduzida segundo a teoria motivacional de Schütz, possibilitou identificar o tipo vivido da enfermeira no cuidado à família da criança hospitalizada, que é apresentado em duas condutas motivacionais. $\mathrm{Na}$ primeira o cuidado da enfermeira é caracterizado por Incluir a família, pois para ela pensar na família é fundamental. Com isso, sente necessidade de atender às demandas da família durante a hospitalização e de aprimorar seus conhecimentos quanto à abordagem da família. Na segunda conduta, o cuidado da enfermeira se caracteriza por Engajar a família na assistência prestada à criança. Para ela a presença da família é importante, e a necessidade de integrar a família no cuidado e atender às demandas da criança são modos de garantir o cuidado futuro da criança. O estudo revelou que a experiência de cuidado à família da criança hospitalizada prestado pela enfermeira não é uniforme, a motivação ainda se dá como prática individual, conforme a bagagem de conhecimento e os propósitos de cada profissional. A implementação de um modelo de cuidado centrado na família, apresenta desafios que demandam superação, individual e institucional, para que também a família seja considerada como unidade de cuidado durante a hospitalização de um seus membros.

PALAVRAS CHAVES: enfermagem da familia, enfermagem pediátrica, fenomenologia, cuidado centrado na familia, familia. 
Sampaio PSS. Family care in pediatrics: experience of nurses in a university hospital. [Dissertation]. São Paulo (SP): School of Nursing, University of São Paulo, 2011.

\begin{abstract}
The purpose of this research was to reveal the phenomenon: the nurse in caring for families of hospitalized children. This qualitative study aimed to understand the experiences of nurses in caring for families of hospitalized children and learn the typical experience of nurses' actions involving such care. It was used as a theoretical philosophical approach the Social Phenomenology of Alfred Schutz. Interviews were conducted with 16 nurses working in pediatric emergency, pediatric intensive care, newborn nursery and pediatric unit at a university hospital in São Paulo city, focusing on their experience in caring for families of hospitalized children. The analysis conducted according to the motivational theory of Schütz, enabled us to identify the experienced type of nurse in caring for families of hospitalized children, which is presented in two motivational behaviors. The first is characterized by Including family in care: the nurse think family as fundamental, needs to meet the demands of the family during hospitalization and improve knowledge to approach the family. The other is characterized by Engaging the family in care: for the nurse, the family presence is important and she needs to integrate the family in care and meet the demands of the child as a way of ensuring the future care of the child. The study revealed that nurses' experience in caring for families of hospitalized children is not uniform, that motivation has emerged as solo practice, in accordance with the baggage of knowledge and purposes of each professional. The implementation of a family-centered care model, presents challenges to overcome, so that the family is considered as the unit of care during the hospitalization of one its members
\end{abstract}

KEYWORDS: family nursing, pediatric nursing, phenomenology, family centered care, family. 


\section{SUMÁRIO}

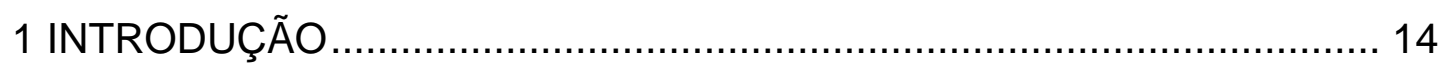

1.1 DESPERTANDO PARA A TEMÁTICA …………............................ 14

1.2 O ENFERMEIRO E O CUIDADO DA FAMÍLIA EM PEDIATRIA ........ 18

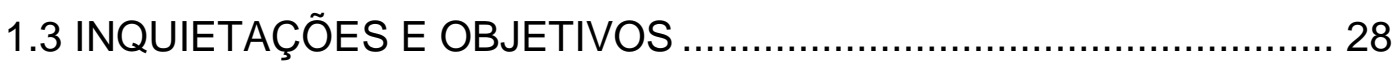

2 OPTANDO PELO REFERENCIAL TEÓRICO-FILOSÓFICO...................... 31

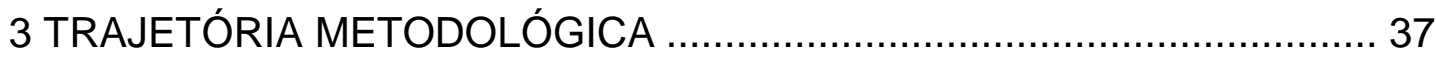

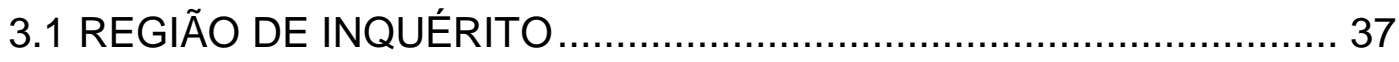

3.2 SUJEITOS DA PESQUISA, ASPECTOS ÉTICOS E COLETA DE

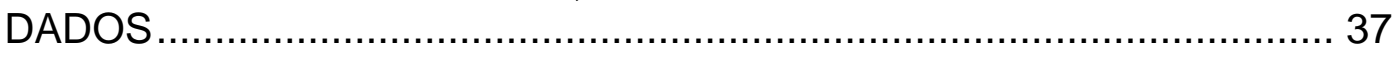

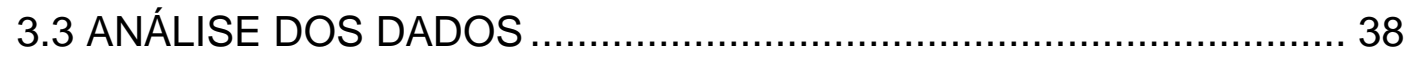

4 CONSTRUÇÃO DAS CATEGORIAS CONCRETAS DO VIVIDO ............. 42

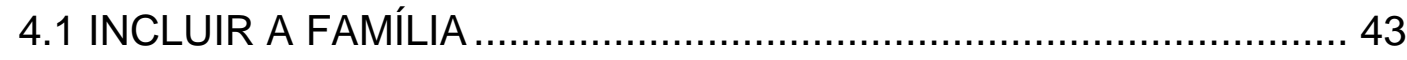

4.1.1 Pensar na família é fundamental ............................................. 44

4.1.2 Atender às demandas da família ............................................. 52

4.1.3 Aprimorar a abordagem à família ........................................... 56

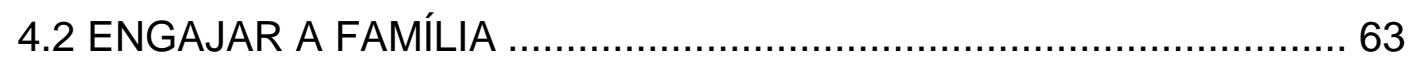

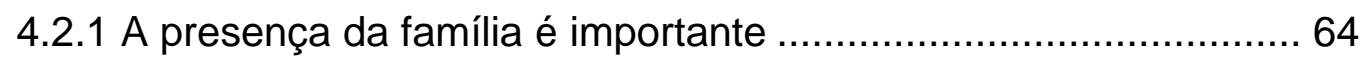

4.2.2 Atender às demandas da criança ............................................. 68

4.2.3 Garantir o cuidado futuro da criança......................................... 70

4.2.4 Integrar a família no cuidado ................................................. 74

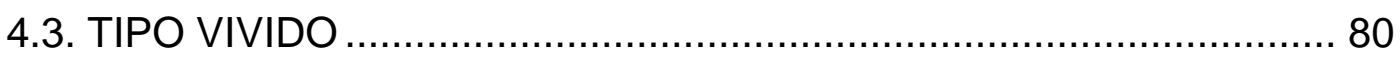

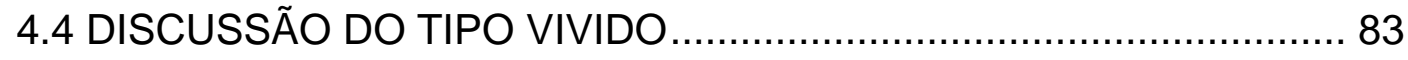

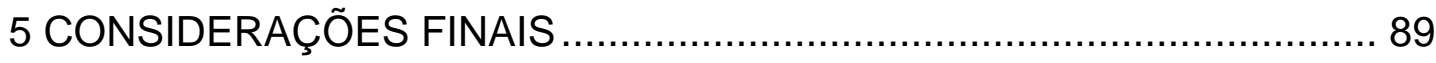

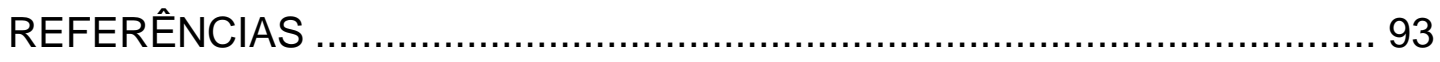

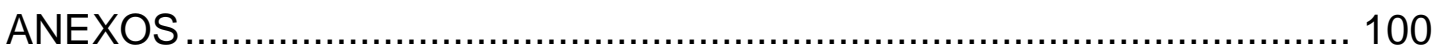


INTRODUÇÃO 


\section{INTRODUÇÃO}

\subsection{DESPERTANDO PARA A TEMÁTICA}

Meu interesse pela temática do enfermeiro pediátrico na prática assistencial à família no processo de doença da criança ocorreu em três momentos de minha vida. O primeiro deles se deu pelo fato de eu ser irmã de gemelares prematuros. $O$ segundo por ser mãe de uma recém-nascida prematura e o terceiro, por fim, porque atuei como profissional de saúde em uma unidade de terapia intensiva neonatal. Assim sendo, esses contextos, embora distintos e vivenciados em épocas diferentes de minha vida, apresentaram um forte impacto sobre mim enquanto pessoa e profissional de saúde.

Primeiramente como irmã, na época com 10 anos, me lembro do sofrimento vivido por minha mãe e do silêncio de meu pai ao nascimento de meus irmãos gêmeos e prematuros - os quais permaneceram internados por um longo período e tiveram alta em momentos diferentes -, bem como de minha incompreensão frente a todo aquele tumulto vivido pela família. Além disso, vivenciei as mudanças que aconteceram posteriormente, com constantes visitas de meus irmãos ao pediatra e outros especialistas, a presença de refluxo gastroesofágico, a maior suscetibilidade que eles tinham às doenças, a administração de medicamentos e a maneira como minha mãe administrava tudo isso.

Observando hoje, percebo como foram difíceis todos aqueles momentos de incertezas, medos e qual seria o impacto que esse advento teria em nossas vidas.

Entre a primeira e a segunda experiência, ingressei no ensino superior em enfermagem, no qual tive contato com crianças e recémnascidos hospitalizados durante os estágios, e pude perceber uma dedicação maior referente ao bem-estar do outro, em especial recémnascidos em situação de hospitalização.

Nessa época foram surgindo oportunidades de conviver com crianças em situação de doença, com a propiciação de prestar atenção não somente a elas, mas também para a família, concretizando um sonho já alimentado. 
Passava, portanto, longos períodos em contato com as famílias, na tentativa de ajudá-los de alguma maneira e assim diminuir seus sofrimentos, que pareciam ser muitos e de naturezas diversas, respeitando-os e acolhendo-os na medida das minhas possibilidades de pós-adolescência.

Também percebia que a maioria dos profissionais tentava explicar o motivo pelo qual a criança se encontrava hospitalizada, muitas vezes sem notar o impacto de suas palavras sobre aquelas famílias.

Alguns profissionais, além de fornecerem informações sobre o estado de saúde das crianças, também perguntavam às famílias como estava sendo vivido aquele período. Eles eram, sem dúvidas, lembrados pelas famílias não somente pelos procedimentos técnicos realizados, mas também pela atenção dispensada nos momentos de maior necessidade.

Naquele momento de minha vida comecei a tomar consciência do papel social do enfermeiro no processo de cuidado.

A segunda vivência se deu no ambiente de Terapia Intensiva Neonatal, com o advento do nascimento prematuro da minha primeira filha e sua necessidade de hospitalização nesse setor.

Por meio dessa experiência pude confirmar a diversidade e intensidade de sentimentos que dela decorrem, como medo, angústia, impotência, raiva, e esperança, os quais permeiam toda a família durante a hospitalização do bebê e sua necessidade de amparo, para que, mesmo diante de tantas incertezas acerca do futuro, sua sobrevivência seja garantida. Assim sendo, dentro dos limites aos quais éramos submetidos em relação ao tempo de permanência na unidade, fui realizando cuidados gerais, como amamentação e toque, e que também se manifestaram por meio das pequenas formas de me fazer presente em sua luta. Dessa maneira ia percebendo o seu progresso até o momento da alta hospitalar.

Em algumas situações, contudo, não sabia como ou com quem compartilhar a quantidade de sentimentos que me acometiam.

Percebia que os profissionais de saúde não notavam com tanta clareza as necessidades dos pais diante do impacto causado pela internação de um filho em unidade de alto risco. Faltava-Ihes também a percepção da repercussão que aquela experiência poderia vir a ter em suas 
vidas, visto que a hospitalização de um membro da família reflete em todos os outros membros. A experiência com meus irmãos trouxe-me essa consciência.

Notava o desvelo com que os recém-nascidos eram cuidados pela equipe durante a realização tanto de procedimentos altamente técnicos e especializados como intubação, quanto de procedimentos rotineiros, tal qual a troca de fraldas.

Mas foi a partir de 1992, em Salvador/ BA, que dei início à minha vida profissional como enfermeira assistencial em uma Unidade de Terapia Intensiva Neonatal de um hospital de médio porte, referência no cuidado ao recém-nascido de alto risco. O exercício das atividades era uma tarefa desafiadora face à complexidade característica dessa faixa etária, mas igualmente gratificante, por me permitir ter acesso à família e entender de que forma poderia auxiliá-la.

Esse fato corroborou sobremaneira para o olhar que eu dirigiria à família durante o processo de hospitalização do seu filho, pois, mediante minha situação biográfica, sabia que aquela experiência mudaria a vida daquele núcleo.

Com isso, fui adquirindo conhecimentos técnicos, necessários no atendimento ao recém-nascido em Unidade de Terapia Intensiva Neonatal, ao mesmo tempo em que me aproximava dos pais, ouvindo-os (e seus sentimentos eram importantes), sensibilizando-me com suas histórias, percebendo a diferença que faziam os momentos que eram dedicados à família, bem como a parceria com a mesma por meio da confiança que íamos conquistando durante a hospitalização de seu filho. Esses fatores, somados à minha experiência de ter tido um filho em situação semelhante, facilitava a nossa aproximação.

Desta forma, a cada família que assistia, sentia que a qualidade de meu trabalho aumentava, no sentido de conseguir ajudar o outro.

À medida em que fui amadurecendo com a diversidade de experiências na prática clínica, faltavam-me elementos conceituais, teóricos, consistentes, para promover mudanças práticas no cuidado com as famílias no meu ambiente profissional, o que gerou em mim as seguintes 
indagações:

1. Os enfermeiros pediatras cuidam da família da criança hospitalizada no seu dia a dia?

2. Qual a abordagem que eles utilizam na realização desse cuidado?

3. Como e por que eles realizam determinada abordagem com as famílias na sua prática?

4. Quais os motivos que os levam a cuidar ou não das famílias?

Mesmo sabendo que a família é parte fundamental do cuidado de enfermagem, não sendo desvinculada da criança, principalmente em situação de doença, sentia que alguns colegas eram sensibilizados e se inquietavam com essa questão, mesmo sem terem consistência teórica. Outros não estavam sequer sensibilizados, tendo como foco de cuidado apenas a criança e sua enfermidade.

Entendo hoje que o fato do profissional não estar sensibilizado ocorre devido à própria formação acadêmica, que não insere a família como parte da unidade de cuidado, e sim dentro da visão biomédica, em que o foco é a doença.

Sei que a sensibilização interfere na motivação pessoal do enfermeiro, no sentido de buscar recursos e criar formas adequadas de ser e atuar com a família nesse contexto. E ainda que esteja sensibilizado, sem a instrumentalização torna-se inconsistente para realizar intervenções e modificar a realidade do ambiente hospitalar ${ }^{1}$.

Assim sendo busquei, por meio da inserção acadêmica como mestranda na Universidade de São Paulo, conhecer uma abordagem em que a família é o foco do cuidado e sua importância no contexto de hospitalização da criança. 


\subsection{O ENFERMEIRO E O CUIDADO DA FAMÍLIA EM PEDIATRIA}

Pesquisas mostram a relevância em compreender a história e o desenvolvimento da abordagem centrada na família, apropriando-se, assim, da importância desse tema, o qual tem suscitado pesquisas, discussões e reflexões em todas as áreas do conhecimento da enfermagem ${ }^{2,3}$.

Corroborando, estudos vêm apontando para a necessidade de inserir a família como unidade de cuidado no contexto hospitalar da enfermagem pediátrica.

Nesse sentido a literatura traz textos que têm como foco mostrar o surgimento das bases teóricas e conceituais do cuidado centrado na família ${ }^{2-7}$ e sua importância para a saúde da mesma.

Até meados da década de 20, a presença dos pais durante a internalização das crianças não era permitida. Essa restrição resultava em traumas, devido aos longos períodos que passavam internadas, na sua maioria para tratamento de doenças crônicas ${ }^{4}$.

Porém, a $2^{\text {a }}$ Guerra Mundial trouxe consigo uma preocupação crescente com a saúde psicológica dos adultos jovens e das crianças, visto que muitas crianças foram separadas de suas famílias. Esse fenômeno gerou angústias e traumas psicológicos, fazendo com que os psicólogos voltassem suas atenções para as implicações negativas dessa dissolução ${ }^{4}$.

Nesse sentido deve-se ao teorista John Bowlby, quem elaborou os construtos do apego, e aos Robertsons, os quais deram origem ao conceito de hospitalismo, os créditos do inicio do desenvolvimento do Cuidado Centrado na Família, uma vez que colocaram em pauta o trauma psicológico vivido pela família².

Esse início foi marcado pelo movimento de apoio familiar a crianças com necessidades especiais e mentais, bem como pelos movimentos dos consumidores ${ }^{2}$.

Assim, o movimento familiar foi baseado nos seguintes pressupostos:

- A abordagem mais efetiva para as famílias emana de uma perspectiva de saúde e bem-estar. 
- A capacidade dos pais educarem as crianças de maneira efetiva é influenciada pelo desenvolvimento deles próprios.

- As técnicas utilizadas pelos pais para criar seus filhos são influenciadas por valores culturais, costumes e comunidade.

- Redes de apoio social são essenciais para o bem-estar da família.

- Informações sobre o desenvolvimento da criança aumentam a capacidade dos pais de responder adequadamente a seus filhos.

- Família que recebe apoio está habilitada a advogar em seu próprio nome.

Essa mobilização contínua de mudanças na forma como as crianças hospitalizadas eram cuidadas, chegando até mesmo a ter o acompanhamento de seus familiares durante a hospitalização, teve um impacto profundo na enfermagem. De opiniões divididas passou-se para a aceitação desse conceito, ao menos teoricamente ${ }^{2}$.

O contexto histórico de todos os acontecimentos culminou com efeitos na sociedade e originou artigos e pesquisas sobre a importância do envolvimento familiar na hospitalização infantil.

A partir desse movimento, foram desenvolvidos os princípios que caracterizam a filosofia produzida pela Associação para os Cuidados de Saúde para a Infância (ACCH), em 1987, por Shelton et al. Em 1990 foi incorporado mais um elemento, totalizando nove princípios da abordagem centrada na família, os quais são mantidos até o momento ${ }^{6}$.

Desta forma, os nove princípios que o compõem são:

$\checkmark$ Reconhecer que a família é uma constante na vida da criança, enquanto os serviços pessoal e de saúde no âmbito desses sistemas são flutuantes.

$\checkmark$ Facilitar a colaboração do pai/profissional em todos os níveis da saúde.

$\checkmark$ Partilhar informações completas e não enviesadas com os pais sobre seus filhos numa base contínua e apropriada, e de modo de suporte.

$\checkmark$ Planejar políticas e programas que sejam compreensíveis e prover suporte emocional e financeiro que atendam às necessidades da família. 
$\checkmark$ Reconhecer os pontos fortes da família e a individualidade e respeito pelos diferentes métodos de enfrentamento.

$\checkmark$ Compreender e incorporar as necessidades de desenvolvimento dos lactentes, crianças e adolescentes e suas famílias no sistema de prestação de serviço de saúde.

$\checkmark$ Encorajar e facilitar o suporte entre os pais.

$\checkmark$ Garantir que a concepção de sistemas de prestação de cuidados de saúde seja flexível, acessível e receptiva às necessidades da família.

$\checkmark$ O planejamento do cuidado deve ser flexível, incluindo a competência cultural que responda às necessidades da família.

Fundado nos EUA em 1992, para aprofundamento e prática avançados no cuidado centrado na família, o Instituto para o Cuidado Centrado na Família define sua abordagem como "uma forma de cuidar da criança e de seus familiares garantindo um cuidado planejado em torno da família inteira, e por meio da qual todos os membros são reconhecidos como beneficiários" e adotam também os mesmos elementos norteadores ${ }^{2,5}$.

No sentido de responder às indagações que me motivaram na construção dessa pesquisa, formulei os seguintes questionamentos: Qual a experiência do enfermeiro na assistência à família da criança hospitalizada? Que abordagem ele utiliza? O cuidado centrado na família possui uma abordagem presente?

Para o levantamento dos artigos e a realização da revisão foram utilizadas duas bases de dados, a saber: Scopus e MEDLINE (Medical Literature Analysis and Retrieval Sistem on-line).

Os critérios de inclusão dos artigos definidos inicialmente para a presente revisão foram:

> Artigos publicados em português e inglês com resumo disponível nas bases de dados, no período compreendido entre 2000 e 2010;

> Artigos publicados cuja metodologia adotada permitisse obter evidências fortes sobre a temática;

> Artigos que retratassem a vivência, visão e ações dos enfermeiros na assistência à família de crianças hospitalizadas;

$>$ Artigos que tivessem como autor um enfermeiro. 
Devido às particularidades para 0 acesso às duas bases de dados escolhidas, as estratégias usadas para a seleção dos artigos foram adaptadas de acordo com cada uma, tendo como eixo norteador a pergunta e os critérios de inclusão.

Foram utilizadas as palavras-chaves "family centered care", "nursing", "pediatric", "pediatric nursing" e localizadas 409 referências bibliográficas. Após a leitura dos resumos, selecionei os artigos publicados a partir dos critérios de inclusão. A análise permitiu a seleção de 52 artigos.

Dentre os artigos selecionados, $56 \%$ foram publicados em periódicos internacionais (norteamericanos, europeus). O restante (44\%) foi publicado em periódicos nacionais, na sua maioria da região Sudeste, sobretudo São Paulo, sendo que $68 \%$ são pesquisas qualitativas e as demais (32\%) se tratam de revisões de literatura, relato de experiência, reflexão e pesquisas quantitativas.

As evidências dos estudos após análise foram agrupadas em 2 temas centrais: A- novo foco do cuidado; B- o impacto da abordagem na comunicação/interação com a família, que estão descritos a seguir.

\section{(a) Novo foco do cuidado}

Essa categoria reúne os estudos que demonstram como os enfermeiros vêm inserindo a família como unidade de cuidado por meio do estabelecimento, implantação e seguimento de teorias, conceitos, normas e rotinas relacionados ao período de hospitalização das crianças, bem como as dificuldades encontradas na sua aplicação.

O modelo do Cuidado Centrado na Família já é aplicado, e seus princípios norteadores são valorizados pelos enfermeiros ${ }^{8-14}$.

Um estudo que objetivou mostrar como se deu a implantação do modelo de cuidado centrado na família em unidade de cuidados pós operatórios ${ }^{8}$ comparou inicialmente os benefícios potenciais para as crianças e as barreiras e mitos dos enfermeiros, a fim de justificar tal mudança.

Resistência nesse momento é esperada e deve ser entendida e acolhida, visto que o que era considerado como correto torna-se passado. Outro fator relevante foram pesquisas com prática baseada em evidência ${ }^{8}$. 
Os elementos propostos nessa abordagem alteram e modificam os padrões de prática clínica, passando do cuidado da criança para a inclusão da família ${ }^{15}$.

Nesse sentido, uma vez desenvolvido o Cuidado Centrado na Família como filosofia durante a implantação em unidades pediátricas, as melhorias são realizadas até que se transforme em uma cultura ${ }^{11}$, em que o paciente, mesmo sendo criança, é considerado uma pessoa com família, desejando um tratamento digno e respeitoso ${ }^{10}$.

A família vem se tornando o foco do cuidado ${ }^{9-12,15-17}$. Sua participação gera segurança, confiança e tranquilidade para a criança, a família e o próprio enfermeiro $^{2,16}$. Dessa maneira se dá o restabelecimento parental, que repercute nos enfermeiros e os auxilia no respeito aos valores e sentimentos familiares, estabelecendo assim uma parceria no cuidado à criança hospitalizada ${ }^{18,19}$.

A busca em descobrir conceitos e buscar aprimoramento possibilita aos enfermeiros cuidar das famílias, o que inclui dentre outras coisas seus conhecimentos, suas demandas e suas experiências ${ }^{20-22}$, assim como discussão e reavaliação das regras institucionais, flexibilidade e exceções ${ }^{16}$.

O tempo de experiência reflete no uso do Cuidado Centrado na Família de forma mais consistente, sendo explicado pelo enfoque como o treinamento dado na década passada de forma filosófica, e seu conceito foi se desenvolvendo ao longo dos anos, o que possibilitou que os enfermeiros menos experientes se apropriassem de sua aplicação ${ }^{9,23}$.

Os setores pediátricos que utilizam o conceito do Cuidado Centrado na Família percebem que há uma diminuição no tempo de internação e complicações pós-cirúrgicas, o que incentiva a equipe a trabalhar em conjunto, consultando-se sobre a melhor forma de abordar a família, efetuando cuidado colaborativo e tomando decisões conjuntas no interesse da criança ${ }^{24}$.

Em unidades como a de terapia intensiva e centro cirúrgico, a presença dos pais é considerada importante durante procedimentos invasivos ou dolorosos, ressuscitação cardiopulmonar, indução e término anestésico ${ }^{14,24,25}$. 
Corroborando essa afirmativa tem-se que a capacidade de enfrentamento por parte da criança aos diversos tipos de procedimentos, sejam eles cirúrgicos ou clínicos, deve-se ao suporte que lhe é oferecido. $O$ fato da família estar ao lado ${ }^{9,10,24}$ garante autonomia, independência e colaboração da criança ${ }^{14,25}$.

Embora os enfermeiros saibam que a presença dos pais para os filhos hospitalizados seja estabelecida por lei, ainda não é uma realidade na maioria das instituições, visto que muitos a desrespeitam por não saberem lidar com situações novas. Essa modificação implicaria mudanças na rotina hospitalar, no desenvolvimento de ações e nas relações sociais em que os pilares ainda são a burocracia, o poder, a hierarquização, a rigidez e a administração não participativa ${ }^{3}$.

O conceito que cada enfermeiro traz sobre família, seus valores, crenças e culturas influencia direta ou indiretamente na aceitação de compartilhar com a família o ambiente hospitalar que antes era só seu. A presença dos pais e convivência com eles por parte dos enfermeiros pode gerar momentos conflitantes na unidade pediátrica ${ }^{3,20,26}$.

Valores como confiança, esperança, segurança, verdade, honestidade, respeito, consideração, compaixão, solidariedade, afeto, amizade, estima, acolhimento, motivação, empatia, dentre outras experiências, são aprendidas com a criança e sua família durante a hospitalização $24,27$.

Há preocupação em proporcionar aos pais a oportunidade para desenvolver ou estreitar o vínculo afetivo com seus filhos durante o período de hospitalização ${ }^{3}$.

Quando os enfermeiros redefinem-se e conhecem a si próprios, suas crenças, seus valores, seus papéis como cuidadores, seus papéis diante da criança em situação de hospitalização e suas relações com os outros, passam a interagir com a família conscientizando-se de que ela é uma aliada na hospitalização da criança ${ }^{21,28}$.

A percepção consciente de incluir a família como unidade de cuidado suscita angústia nos enfermeiros, levando-os a buscar formas diferentes de interação com a família e deixando-os menos presos para querer cuidar 
dela ${ }^{22}$.

Nesse sentido, quando os enfermeiros sensibilizam-se com 0 sofrimento da família, tornam-se mais solidários, tentando compreender a vivência da criança com seus familiares e, dessa meneira, planejam intervenções que visam amenizar o processo doloroso da internação ${ }^{3}$.

Com o objetivo de compreender a experiência da família que vivencia a situação de doença do filho, foi realizado um estudo o qual evidenciou que os enfermeiros projetam-se no papel de membro da família a fim de imaginar a dor sentida pela hospitalização de um filho. Essa conduta os faz avaliar a profundidade da aflição e do sofrimento dos pais, o que pode levá-los seja a ter uma postura distante e meramente física, seja intimidade com a família a ponto de perceber-se acolhida por ela ${ }^{28}$.

Em um estudo ${ }^{22}$ cuja finalidade foi compreender como ocorre a sensibilização para a família, evidenciou que, ao tentar compreendê-la, os enfermeiros buscam conhecimentos que os ajude a cuidá-la e desenvolver ações que vão ao encontro das necessidades.

Essa aproximação gera prazer e os impulsiona a manter-se em contínuo contato com a família.

Dessa forma percebem que para efetivar o cuidado com a família é necessário estar perto dela e abrir-se para sua experiência, transformando ideias pré-concebidas em relação às suas possibilidades de cuidado no processo de trabalho ${ }^{22}$.

Soma-se o fato de que as dificuldades apontadas em algumas pesquisas ${ }^{10,19}$ vêm em decorrência da vivência com esse tipo de assistência.

O acolhimento dos familiares pelos profissionais de saúde é uma questão de tempo e adaptação, sabendo que esse processo envolve mudança de comportamento, dificuldade de adaptação, medo do novo, angústia e conflitos. O seu sucesso dependerá da forma como os enfermeiros responderem às mudanças ${ }^{3}$.

A visão da equipe multidisciplinar quanto à presença da família em Unidades de Terapia Intensiva Pediátrica e Neonatal, evidencia o conflito vivido pelos enfermeiros já que, ao mesmo tempo em que apresentam dificuldades em ter os pais presentes na unidade, reconhecem a importância 
deles no processo de hospitalização da criança ${ }^{3}$.

Além dos fatores relacionados em concordância nas unidades estudadas, falta-lhes construto teórico que os sustente junto às famílias no seu cotidiano de trabalho ${ }^{3}$.

\section{(b) Modos de comunicação/interação com a família}

Essa categoria engloba os estudos relacionados ao impacto da abordagem dos enfermeiros na comunicação/ interação com a família.

Dentro do processo de comunicação, a negociação é o fator mais importante, uma vez que permite que os pais sejam ouvidos e sintam-se respeitados em suas necessidades, o que os torna parceiros no cuidado com a criança hospitalizada ${ }^{9,10,12,14}$.

Querendo prestar os melhores cuidados possíveis à criança hospitalizada, os pais são vistos pelos enfermeiros como especialistas e os únicos capazes de fornecer informações precisas no que diz respeito ao filho ${ }^{14,25}$.

Essa atitude positiva gera bem-estar aos enfermeiros ao passo que traduz respeito para a criança e seus pais ${ }^{14,25}$.

As informações sobre a evolução da condição da criança prestadas aos pais devem ser honestas, repetidas e atualizadas, sejam elas favoráveis ou desfavoráveis, suscitando-lhes a certeza de que seu filho está recebendo assistência adequada ${ }^{13,18,29}$.

Informações prestadas à família por ocasião da primeira visita dizem respeito a alguns procedimentos de rotina para que permaneçam na unidade, tais como como lavar as mãos, vestir avental, horários de visita para o restante dos familiares, não manipular os aparelhos, participação nos cuidados ${ }^{13,20,27}$, dentre outros.

As informações devem fazer parte da prática cotidiana do enfermeiro, pois contribuem para diminuir a preocupação, o estresse, a ansiedade e a insegurança frente à hospitalização do filho, além de proporcionam aos pais a oportunidade de fazer perguntas sobre seu filho e obter respostas compreensíveis, as quais permitam aos pais conhecer e enfrentar o que está acontecendo com a família ${ }^{8,12,13,17-20,26,27-32}$. 
A conversa informal promove cuidados mais autênticos e individualizados, selando fortes laços interacionais entre os enfermeiros e a família. É tida como um importante início para uma comunicação efetiva entre ambos $2,4,12,13,16,26,2,9,32$.

Informações dadas com frequência, repetidamente, sem pressa e de maneira adequada ao grau de preocupação e compreensão da família, fazem com que a realidade mostre-se para ela minimamente distorcida por fantasias $^{18}$.

As informações devem incluir os aspectos positivos da criança e de sua família ${ }^{18}$.

A comunicação entre os enfermeiros e os pais apresenta-se em alguns estudos como um monólogo: os enfermeiros falam e os pais escutam e acatam, traduzindo a hierarquização e dificultando o relacionamento em parceria $^{3,26}$.

A negociação é um dos elementos geradores de estresse relatados pelos enfermeiros, pois é caracterizada pela dominação - subordinação -, e não de forma dialogada e clara para ambos. Dessa maneira, algumas questões acabam por permanecer implícitas e veladas ${ }^{33}$.

Quanto à tomada de decisão, os enfermeiros sempre negociam com os familiares a assistência prestada à criança, mostrando-se flexíveis e abertos e valorizando a tomada de decisão pela família ${ }^{26,30,34}$.

A comunicação terapêutica é considerada muito importante na abordagem centrada na família com crianças hospitalizadas ${ }^{9,10,19,21}$. Na mesma intensidade, muita informação em momentos inadequados desencadeia ansiedade nos pais,bem como pouca informação pode provocar medo ${ }^{13}$.

No momento da admissão, a presença dos pais/familiares faz com que acriança se sinta mais segura, o que também favorece a criação de vínculo mais forte entre ambos e facilita a maneira como se lida com a hospitalização ${ }^{25,35}$.

A indisponibilidade por parte dos enfermeiros quanto à presença dos pais pode ser caracterizada como falta de respeito aos pais e à criança ${ }^{14}$.

Da mesma forma, pode haver situações em que os enfermeiros têm 
expectativas antecipadas de como os pais devem se comportar, o que pode gerar conflitos entre eles ${ }^{8}$.

Enfermeiros acreditam não haver pessoal suficiente para apoiar os pais emocionalmente, sobretudo na vigência de situações de emergência ${ }^{25}$. Por isso consideram que deveria ser disponibilizado aos pais um membro da equipe que pudesse explicar o que está ocorrendo, bem como lhes oferecer a oportunidade de estar junto ao filho durante situações emergenciais e procedimentos invasivos ou dolorosos ${ }^{10,25}$.

A efetuação desse procedimento diminuiria os riscos dos pais desenvolverem imagens distorcidas ou ideias erradas sobre processo emergencial, e os confortari saber e vivenciar que todos os esforços em prol da sua criança foram realizados.

Em algumas ocasiões, enfermeiros não querem se envolver com a família ou aparecer para ela. Há casos em que evitam abordá-la diretamente quando há ocorrência de sofrimentos emocionais, o que torna a parceria difícil de acontecer ${ }^{14,19,36}$.

Outra dificuldade sentida pelos enfermeiros é a forma de abordagem aos pais ${ }^{8,13,19,31}$ e famílias com pais adolescentes ${ }^{8}$.

Pensando nisso, um estudo aponta para os sentimentos negativos pelos quais a mãe é acometida quando privada dos cuidados ao filho durante o período de internação, que pode durar anos ${ }^{31}$.

Em outro extremo, uma a atitude paternalista dos enfermeiros impede os pais de cuidar de seus filhos, mantendo-os na posição de expectadores 12,14 .

É importante valorizar o conhecimento da família ${ }^{16}$, envolvendo-a na avaliação e tratamento da criança em qualquer fase do processo de hospitalização, a fim de garantir uma intervenção mais efetiva ${ }^{8,9}$.

O estresse e sofrimento vivenciados pela criança no contexto são conhecidos. Por isso a presença dos familiares só tende a trazer benefícios, seja na segurança que confere à criança, no fortalecimento e reestruturação da própria família, na recuperação do filho ou como facilitadora do tratamento ${ }^{16,17,30,37}$.

Para que a família fique satisfeita, entretanto,, é necessário que se 
conheçam suas demandas, seus conhecimentos e habilidades, de maneira que as intervenções sejam abrangentes e contemplem suas necessidades $16,27,37-39$

A importância em aprender a cuidar da família reflete o grau de satisfação na interação do enfermeiro com a mesma, além da percepção de bem-estar referida por ela $\mathrm{a}^{23,28,40}$.

Conclui-se, a partir de todos os fatores suprarreferidos, que sensibilidade e disponibilidade em estar com os pais são percebidas por meio de ações que refletem o reconhecimento deles ${ }^{26}$.

\subsection{INQUIETAÇÕES E OBJETIVOS}

Com base na revisão da literatura foi possível identificar alguns elementos significativos sobre a Abordagem Centrada na Família, sobretudo as limitações por parte dos enfermeiros na realização desse cuidado.

O enfermeiro tem o conhecimento de que o cuidado à família é importante no processo de hospitalização da criança, principalmente no que diz respeito à garantia de sua individualidade, desenvolvimento e diminuição do estresse causado pela internação.

Contudo, ainda se observam por parte de alguns enfermeiros conflitos pessoais e profissionais sobre o cuidado à família como uma unidade a ser cuidada. Há resistência em relação à utilização dessa abordagem, sem o conhecimento das demandas da família, suas potencialidades e recursos. Esses fatores dificultam a restauração do bem-estar da criança e a reestruturação familiar.

Alguns enfermeiros são motivados ao cuidado à família por vários sentimentos e também valores, crenças e conceito de desses familiares, levando-os a buscar novas formas de cuidá-la. No entanto, esses mesmos sentimentos que motivam os enfermeiros fazem com que outros se afastem desse cuidado.

Outro fator motivacional relevante para esse profissional da saúde diz respeito à comunicação e interação com a família. A comunicação efetiva traz reflexos positivos no vínculo da família com os enfermeiros, e deles com 
a criança hospitalizada. A comunicação informal passa a ser uma motivação para que haja interação entre ambos.

Considerando essa abordagem, é necessário que o enfermeiro esteja apropriado de conceitos teóricos aliados às suas motivações, o que resultará em intervenções eficientes no cuidado à família da criança hospitalizada.

Novas inquietações foram suscitadas em mim em decorrência das leituras e respectivas análises:

- Como é para os enfermeiros abordar as famílias de crianças hospitalizadas?

- Quais conceitos de abordagem centrada na família podem ser identificados nas ações dos enfermeiros?

Falando sobre a abordagem centrada na família realizada ao mesmo tempo em que coloquei de lado, temporariamente, o que sabia e pensava, considerando imprescindível ter perscrutado a literatura e apreendido dela aspectos concernentes ao tema, a trajetória desse estudo está voltada para os seguintes objetivos:

- Conhecer a vivência do enfermeiro no cuidado às famílias de crianças hospitalizadas em unidades pediátricas.

- Apreender o típico da vivência dos enfermeiros em ações que envolvem este cuidado.

Este estudo justifica-se, portanto, na medida em que se conhece e compreende o significado do cuidado à família atribuído pelo enfermeiro pediatra durante sua prática. Por meio de suas motivações nesse contexto e intenções futuras obter-se-á subsídios consistentes, a fim de melhor assistir a família com crianças hospitalizadas a partir da utilização de uma abordagem sistematizada nela centrada.

Empenhando-me, agora, na compreensão da motivação dos enfermeiros no cuidado à família, optei por uma abordagem compreensiva apresentada a seguir. 
OPTANDO PELO REFERENCIAL TEÓRICO FILOSÓFICO 


\section{OPTANDO PELO REFERENCIAL TEÓRICO-FILOSÓFICO}

A fim de conhecer e compreender como os enfermeiros realizam, na prática, o cuidado à família no processo de hospitalização da criança, optei pela abordagem da Fenomenologia Social de Alfred Schütz, uma vez que "a fenomenologia possibilita a investigação do cotidiano para a compreensão da realidade concreta com o objetivo de descrever a estrutura total da experiência vivida e como os indivíduos se percebem nessas experiências" 41.

Dessa maneira busquei, por meio da Fenomenologia Social, apreender as motivações que levam o grupo de enfermeiros pediátricos a desenvolver, implementar e planejar ações no cuidado à família, visto que este referencial teórico contempla o mundo das relações sociais (o cuidado da família sob a óptica da enfermeira durante o atendimento pediátrico, neste caso), do qual o foco de interesse é o que pode se constituir como característica típica de um grupo social ao vivenciar uma determinada situação (no caso estudado, o cuidado à família da criança em situação de doença $)^{50}$.

Entende-se que a pesquisa qualitativa é baseada no pressuposto de que o conhecimento sobre os indivíduos só é possível com a descrição da experiência humana, tal como ela é vivida e definida por seus atores ${ }^{42}$. Assim, ela possibilita que "o pesquisador capte a reação dos indivíduos em sua própria realidade. Trabalha com o universo de significados, valores e atitudes dos indivíduos. Permite ao pesquisador conhecer a dinâmica e a situação sob o ponto de vista de quem a vivencia" ${ }^{43}$.

Das diversas modalidades fenomenológicas, a social permite ao sujeito desvelar sua realidade cotidiana de cuidar, podendo apresentar-se diferente sob o olhar de quem cuida (cuidado inautêntico).

Sendo assim, a Fenomenologia Social é expressa como:

Uns pensares filosóficos, voltados à compreensão e interpretação do mundo (...) possibilita ao pesquisado o acesso à consciência humana, isto é, à volta às mesmas coisas, às essências, o que significa chegar à verdade desprovida de estereótipos. Abandonar os preceitos em relação ao fenômeno interrogado ${ }^{44}$. 
Na Fenomenologia Social as crenças e conviç̧ões são reais e fazem parte da experiência vivida pelos enfermeiros pediátricos e do mundo da vida na sua dimensão social, justificando-se a escolha desta modalidade da fenomenologia.

Nesse sentido, a reflexão de Alfred Schütz se faz buscando a fundamentação da vida social tal qual ela se apresenta na cotidianidade da existência. Vale lembrar que Schütz havia utilizado a concepção de consciência do indivíduo de Husserl (a intencionalidade), à qual agregou o método compreensivo de Weber, para interpretar as relações sociais e explicar o comportamento social.

Os construtos essenciais utilizados por Alfred Schütz são o mundo vida, a intersubjetividade, a atitude natural, a situação biográfica, a bagagem de conhecimentos, a ação social, a relação face a face, a conduta motivacional (motivos para e motivos porque), o tipo vivido, o sistema de relevância e a reciprocidade.

"O mundo vida é entendido como um mundo natural, que impõe limite às nossas atitudes, no qual atuamos e operamos como atores e cenário de uma realidade que modificamos mediante nossos atos e que por outro lado transforma nossas ações" ${ }^{\prime 5}$.

Nesse sentido, o mundo vida é entendido como sendo o cotidiano vivido pelo enfermeiro pediátrico no cuidado à família da criança hospitalizada.

A intersubjetividade, de acordo com Schütz, "é o modo pelo qual desde o início nós atores, dentro de um cenário social, experimentamos 0 mundo em que vivemos como um mundo ao mesmo tempo natural e cultural, como um mundo não privado, mas intersubjetivo, isto é, comum a todos nós, realmente dado potencial acessível a cada um" ${ }^{46}$.

Dessa forma, cada profissional de saúde que compõe o grupo de enfermeiros pediátricos dentro da unidade hospitalar, é influenciado e interfere diretamente no cuidado à família.

A atitude natural é referida por Schütz como "a maneira pela qual o homem experimenta o mundo intersubjetivo, inserido no mundo do senso comum, ou mundo cotidiano. Este mundo existia antes do nascimento, tem 
uma história das ações e interações de modo organizado" 46.

No contexto das unidades pediátricas do hospital, busquei compreender a postura dos enfermeiros pediátricos frente às suas motivações no cuidado à família da criança em situação de doença.

A situação biográfica é um conceito para explicar como cada indivíduo se insere nas situações cotidianas utilizando o conhecimento adquirido em suas experiências. O individuo dispõe de um rol de conhecimentos estruturados e significativos que determina o modo de atuar e enfrentar desafios ${ }^{47}$.

Assim, a forma como o enfermeiro pediátrico interpreta o cuidado à criança hospitalizada é resultante daquilo que foi significativo na sua biografia, isto é, as experiências vivenciadas por ele. Schütz descreve da seguinte forma:

Situação biográfica é o modo pelo qual eu ocupo o espaço da ação, interpreto suas possibilidades e me envolvo com seus desafios, e a sedimentação dessa experiência passa a ser a condição para a interpretação subsequente de todos os nossos eventos e desafios (Schütz, 1974).

A bagagem de conhecimento é o conhecimento armazenado durante toda a vida, por meio das experiências vivenciadas e ensinadas por outras pessoas. Segundo Schütz ${ }^{46}$, a bagagem de conhecimento disponível, integrada por tipificações do mundo do sentido comum, determina nossa situação biográfica.

Dessa forma, a bagagem de conhecimentos dos enfermeiros pediátricos acerca do cuidado à família se dá pelas experiências vividas individualmente agregadas às experiências adquiridas por meio da experiência vivida pelos outros.

A ação social expressa o sentido que a pessoa atribui ao mundo. É uma conduta voluntária, orientada pelo passado, presente e futuro. $\mathrm{O}$ ato constitui uma ação concluída. A ação social é uma atividade humana intencional e de projeção, originada na consciência das pessoas, vivida de modo singular e contextualizada na intersubjetividade "da realidade social" 48 . 
No presente estudo, a ação social representa as atividades que os enfermeiros pediátricos realizam no cuidado à família da criança doente.

Schütz chama relação face a face àquela na qual eu apreendo diretamente o outro, ou seja, "outra pessoa está dentro do alcance de minha experiência direta quando compartilha comigo o mesmo espaço e o mesmo tempo. Quando eu percebo esse indivíduo, sua experiência flui lado a lado com as minhas" 47 .

Compreende a relação direta que o enfermeiro pediátrico compartilha com a família durante o cuidado da mesma.

A conduta motivacional é o conjunto dos motivos pelos quais e para que Schütz se refere. As motivações do indivíduo apontam para o futuro (motivo para) e explicam o projeto em função das vivências passadas, da bagagem de conhecimento adquirida pela vivência pessoal e transmitida pelos antecessores (motivo por que) ${ }^{47}$.

Por analogia, os motivos por que estão relacionados à explicação das ações executadas pelos enfermeiros, assim como os motivos para estão relacionados às ações que poderão ser implementadas para a melhoria do cuidado à família da criança enferma.

Para o tipo vivido, segundo Schütz, "existe um só motivo típico no que diz respeito a um ato típico, originário da mesma base do contexto de significados, isto é, a unidade de ação de outra pessoa é só um corte transversal que o observador extrai do contexto fático total. O tipo vivido está determinado sempre em si mesmo pelo ponto de vista do intérprete, permitindo uma nova perspectiva, e variará de acordo com seus interesses e problemas" $^{49}$.

Similarmente, busquei nos enfermeiros pediátricos a forma que caracteriza as ações e intenções convergentes realizadas no cuidado à família.

A relevância compreende zonas de conhecimento, pressuposto que não percebemos com exatidão As relações interativas entre as pessoas permitem a participação de todos em um mesmo mundo intersubjetivo que, compartilhado com outros indivíduos, torna-se comum a todos ${ }^{49}$. Esse mundo terá influência em mim e eu, como consequência, terei influência nos 
outros. O mesmo objeto aparece de modo diferente para cada indivíduo, o que expressa o mundo social em sistemas coordenados.

Quando uma pessoa entra em contato com outra, surge a possibilidade de adquirir conhecimento pela troca. Mas o objetivo desse conhecimento nem sempre é igual para ambas. A possibilidade de compartilhar conhecimentos faz com que o pensamento do senso comum supere as diferenças de perspectivas individuais, possibilitando a troca de pontos de vistas e atribuindo aos fatos um significado comum ${ }^{49}$.

Da mesma forma, o cuidado à família prestado pelos enfermeiros pediátricos gera impacto tanto para o enfermeiro quanto para a família da criança.

A reciprocidade das perspectivas é constituída por construções tipificadas de objetos de pensamentos que resultam das próprias experiências e seus semelhantes. Por meio dessas construções de pensamento do senso comum, o pressuposto de um torna-se também o de outro $^{49}$.

Nesse sentido, deve existir uma relação de troca entre a assistência de enfermagem prestada à família da criança hospitalizada e o resultado dessa assistência sobre a saúde da família, resultando numa reação de retorno do cuidado aos enfermeiros.

Portanto, todos os construtos supracitados convergem para a interpretação dos discursos dos enfermeiros pediátricos no cuidado à família, o que justifica a utilização do Referencial Teórico Filosófico de Alfred Schütz. 
TRAJETÓRIA METODOLÓGICA 


\section{TRAJETÓRIA METODOLÓGICA}

\subsection{REGIÃO DE INQUÉRITO}

“A região de inquérito é a região de perplexidade, o local transparente das preocupações do pesquisador, não um espaço denominado físico, mas sim um contexto conceitual, em que as pessoas experienciam situações vividas, o local em que o próprio fenômeno acontece" 50 .

Desse modo, a região de inquérito será o mundo da vida dos enfermeiros que cuidam das famílias de crianças hospitalizadas que atuam em unidades pediátricas do Hospital Universitário da Universidade de São Paulo.

O motivo desta escolha se deu pelo fato de se tratar de um hospital de ensino e referência para o processo de cuidado em enfermagem e, portanto, que apresenta grande potencial para estudos referentes ao cuidado da família.

\subsection{SUJEITOS DA PESQUISA, ASPECTOS ÉTICOS E COLETA DE DADOS}

O desenvolvimento desta pesquisa foi iniciado após a aprovação do Comitê de Ética e Pesquisa do Hospital Universitário ( Anexo 1).

Às enfermeiras foram explicitados verbalmente os objetivos e as estratégias do estudo e a necessidade de que fossem gravadas. Frente à manifestação de concordância na entrevista, as mesmas foram realizadas em data, locais e horários de escolha dos participantes da pesquisa, em ambiente reservado, arejado, privativo, com garantia de anonimato e o direito de que se retirassem do estudo em qualquer momento caso julgassem conveniente, conforme previsto na Resolução 196/96 do Conselho Nacional de Saúde sobre pesquisa com seres humanos ${ }^{51}$.

Assim, após o consentimento verbal, foi formalmente lido e assinado em duas vias, por mim e pelo sujeito à pesquisa, o Termo de Consentimento Livre e Esclarecido (Anexo 2) e atribuído um número em substituição aos nomes. 
Fizeram parte do estudo 16 enfermeiras, as quais atuam em unidades pediátricas da Instituição, como segue: Unidade de Internação (4), Pronto Atendimento Infantil (4), Unidade de Cuidados Intensivos Pediátricos e Neonatais (4) e Unidade Neonatal (4). Os critérios para a inclusão das enfermeiras foram a experiência em Unidade Pediátrica do Hospital e a disponibilidade em fornecer a entrevista.

A idade das enfermeiras entrevistadas distribuiu-se entre 26 e 54 anos, e o período de atuação na área pediátrica variou de 4 a 29 anos. Quanto à formação acadêmica, o tempo de graduação variou entre 4 anos e meio e 30 anos. Das profissionais, 11 possuem especialização em enfermagem na área pediátrica, 4 têm especialização em outras áreas da enfermagem, 4 possuem mestrado em enfermagem na área de pediatria, 3 têm mestrado em outras áreas da enfermagem e 2 estão cursando o doutorado.

A coleta de dados ocorreu entre abril e setembro de 2010, por meio de entrevistas.

As questões norteadoras foram elaboradas para possibilitar que os enfermeiros descrevessem como cuidam da família de crianças hospitalizadas em suas unidades, com o intuito de chegar à essência do fenômeno.

Assim sendo, o presente estudo teve duas questões norteadoras:

"Como você vivencia o cuidado da família de uma criança hospitalizada"?

"O que você espera desse cuidado"?

Os discursos foram gravados e transcritos na íntegra.

\subsection{ANÁLISE DOS DADOS}

A fim de compreender a essência do fenômeno a ser desvelado e sua ação no cuidado, abstive-me de opiniões e conceitos pré-estabelecidos, para poder assim me aproximar dele e descrevê-lo tal como se mostrou na sua pureza, pois como salienta Garnica ${ }^{54}$, "o fenômeno buscado é posto em suspensão, o pesquisador despe-se de seus referenciais teóricos prévios, 
permanecendo somente os pressupostos vivenciais - ou o pré-vivido ou o pré-reflexivo".

Wagner ${ }^{48}$, citando Schütz, refere que:

$\mathrm{Na}$ interpretação subjetiva, ao se querer estudar as ações humanas, o cientista pergunta que modelo de mente individual pode ser incluído e quais conteúdos típicos podem ser a eles atribuídos, a fim de explicar os fatos observados como resultado da atividade dessa mente, numa relação compreensível. O postulado da interpretação subjetiva deve ser entendido no sentido de que todas as explicações científicas do mundo social podem e têm de referir-se ao significado subjetivo das ações dos seres humanos das quais se origina a realidade social.

O desenvolvimento de um sistema ordenado de conteúdos significativos envolve vários passos e exige uma organização sistematizada que permitirá responder ao objetivo do estudo e às questões norteadoras. Para proceder à análise individual dos discursos, percorrerei os passos de pesquisadores da Fenomenologia Social, como Merighi ${ }^{4}$.

Assim sendo, o percurso para a análise compreensiva do fenômeno foi realizado gradativamente, da seguinte maneira:

- Leituras atentivas e criteriosas de cada depoimento na íntegra, procurando, primeiramente, identificar e apreender o sentido global da experiência vivenciada pelo enfermeiro.

- Agrupamento dos aspectos significativos extraídos dos discursos dos enfermeiros, os quais representaram convergência de conteúdos que compuseram as categorias concretas identificadas.

- Releitura das transcrições, identificando categorias concretas, isto é, locuções de efeito que expressaram aspectos significativos da compreensão e vivência dos motivos dos enfermeiros relativos ao cuidado à família de crianças hospitalizadas, bem como o que esperaram com esse atendimento.

- Identificação de categorias concretas, as quais abrangeram os atos dos participantes, bem como dos significados do ato social relacionado às ações dos enfermeiros ao cuidarem da família de crianças hospitalizadas e, pela tipicidade dos discursos dos participantes, a obtenção da tipologia vivida. 
- Análise dos agrupamentos de significados segundo o pensamento do fenomenólogo Alfred Schütz, fio condutor na discussão e análise dos dados.

"A análise fenomenológica não se encerra na descrição do subjetivo, mas o viver com - o intersubjetivo - permite a compreensão e interpretação que não é do pesquisador, já que abrange o histórico social e contextualizado do pesquisado" ${ }^{24}$.

"Os fatos para uma pesquisa social fenomenológica são coletados no mundo social de tal modo que nossa experiência científica possa apresentálos sob uma forma segura. Descrevemos e analisamos esses fatos agrupando-os em categorias pertinentes, e estudamos a forma de suas regularidades e o modo como se desenvolvem"48. 
CONSTRUÇÃO DAS CATEGORIAS CONCRETAS DO VIVIDO 


\section{CONSTRUÇÃO DAS CATEGORIAS CONCRETAS DO VIVIDO}

\section{DIAGRAMA DAS CATEGORIAS DA CONDUTA MOTIVACIONAL DAS ENFERMEIRAS}

\begin{tabular}{|c|c|}
\hline Categorias & Subcategorias \\
\hline \multirow{3}{*}{ INCLUIR A FAMÍLIA } & $\begin{array}{l}\text { Pensar na família é fundamental } \\
\text { (motivo porque) }\end{array}$ \\
\hline & $\begin{array}{l}\text { Atender às demandas da família } \\
\text { (motivo porque) }\end{array}$ \\
\hline & $\begin{array}{c}\text { Aprimorar a abordagem à família } \\
\text { (motivo para) }\end{array}$ \\
\hline \multirow{4}{*}{ ENGAJAR A FAMÍLIA } & $\begin{array}{l}\text { A presença da família é importante } \\
\text { (motivo porque) }\end{array}$ \\
\hline & $\begin{array}{l}\text { Atender às demandas da criança } \\
\text { (motivo para) }\end{array}$ \\
\hline & $\begin{array}{l}\text { Garantir o cuidado futuro da criança } \\
\text { (motivo porque) }\end{array}$ \\
\hline & $\begin{array}{l}\text { Integrar a família no cuidado } \\
\text { (motivo para) }\end{array}$ \\
\hline
\end{tabular}

O cuidado à família na experiência da enfermeira é permeado por várias motivações relacionadas aos conhecimentos existentes e às experiências adquiridas ao longo da vida (motivos porque), bem como às relacionadas às suas ambições, aspirações, sonhos, e projetos futuros. Dáse também por meio das ações baseadas na própria vivência (motivos para) singular, isto é, sua bagagem de conhecimentos adquirida ao longo da vida.

Dessa forma, considerando os objetivos propostos de conhecer a vivência do enfermeiro no cuidado às famílias de crianças hospitalizadas e apreender o típico da vivência deles em ações que envolvem esse cuidado à partir dos pressupostos do fenomenólogo Alfred Schütz, foi possível compreender duas condutas motivacionais da enfermeira no cuidado aos familiares: "Incluir a família" e "Engajar a família". Embora cada experiência 
seja única, os resultados indicam estilos típicos em que o cuidado a ela se manifesta na experiência do mesmo grupo de sujeitos. Para uma melhor compreensão da experiência, cada contexto motivacional será apresentado separadamente, com a explicitação das categorias que possibilitaram a sua construção.

\subsection{INCLUIR A FAMÍLIA}

A vivência da enfermeira do cuidado à família nesta conduta motivacional tem como principal motivação apreender a experiência da mesma, com o propósito de aliviar e/ou minimizar o seu sofrimento e fortalecê-la diante do enfrentamento da doença e hospitalização de seus filhos.

A ação executada pela enfermeira nesse estilo de cuidado à família é motivada pela crença de que os membros são uma unidade de cuidado que sofre o impacto da doença e que, portanto, precisa se reestruturar para atender às necessidades da criança e dela própria.

Incluir a família significa não somente cuidar da criança doente, mas abranger a família no cuidado. Dessa forma, as ações são direcionadas para o bem-estar familiar, em que a criança está inserida.

Incluir a família é um processo que vai sendo construído pela enfermeira ao longo do tempo, envolvendo a equipe multiprofissional, já que a profissional se sente motivada a multiplicar e incorporar esse conhecimento à prática de cuidado do serviço.

A enfermeira motiva-se para efetuar um cuidado que inclua a família de forma efetiva, aprimorando o conhecimento acadêmico no sentido de garantir a qualidade de assistência à família. Dessa forma ela se propõe a sustentar e embasar suas argumentações para a equipe multidisciplinar quanto à essencialidade de se pensar nos familiares. Essa perspectiva ampliada que a enfermeira possui sobre o cuidado à família propicia a realização de uma assistência baseada na família como unidade de cuidado, motivada pela crença de que, utilizando-se de seus próprios recursos, será capaz de atender às suas necessidades. 
Apoiando-se na intersubjetividade na interpretação dos dados fornecidos pela família, a enfermeira também se coloca de forma sistematizada, para que suas ações sejam observadas, validadas e reproduzidas seja pela equipe diretamente vinculada a ela seja pela equipe multidisciplinar. Pelo fato dessa necessidade de cuidado à família ser contínuo, faz-se necessário o auxílio de um grupo social e, por ser referência, não fica só na unidade, e seu conhecimento deve ser passado adiante.

A motivação da enfermeira em incluir a família é baseada não no julgamento pessoal dessas necessidades, e sim nas demandas trazidas pelos próprios familiares. A enfermeira tem consciência de sua atitude social no cuidado à família.

Nesse sentido, sua motivação abrange a intersubjetividade, o mundo vida e a relação face a face na interação que estabelece com a família durante seu cuidado.

Com o intuito de tornar a abordagem de incluir a família uma cultura na unidade pediátrica, a enfermeira se motiva pela necessidade contínua de manter um desenvolvimento em relação a si própria enquanto inserida em um mundo social.

PROPOSIÇÃO 1: Incluir a família no cuidado é essencial para a assistência pediátrica.

\section{SUBCATEGORIA:}

\subsubsection{Pensar na família é fundamental}

Nessa conduta a enfermeira reflete o cuidado à família em situação de doença durante suas ações cotidianas.

Nesse ínterim, criança e família não se dissociam para a enfermeira. Sua motivação reside na crença de que a condição de uma afeta diretamente a da outra. Pensando nisso, a profissional considera o problema como sendo da família e não apenas da criança.

A enfermeira alia seu cuidado à família às suas motivações pessoais sobre ela, bem como à sua própria bagagem de conhecimentos, para poder 
assim efetivar seu cuidado e realizá-lo voltando-se para a família.

Além disso, a enfermeira também utiliza sua própria situação biográfica para prestar os cuidados à família da criança.

A profissional da saúde é motivada a fim de modificar todo o contexto da hospitalização para a família e conferir a ela o direito de interceder em prol de sua criança.

Motivada pelo objetivo de minimizar os riscos na família e na criança causados pela hospitalização - e assegurar que os familiares continuem a se desenvolver com nenhum ou com o menor risco de sequelas emocionais e/ou físicas, a enfermeira os inclui no processo de cuidado na situação de doença.

\subsubsection{Enfermeira é responsável pela mudança no cenário}

A fim de incluir a família no cuidado, a enfermeira é motivada pelo reflexo que o seu comportamento tem no restante da equipe e, por conseguinte, na responsabilidade dos seus atos e suas consequências.

Assim sendo, sentindo-se um modelo para sua equipe, a enfermeira se motiva tendo ações que geram comportamento semelhante no seu grupo e que será capaz de promover mudanças efetivas na maneira de cuidar das famílias. Essa conduta torna a equipe apta a assisti-la e faz com que aprenda continuamente.

Nesse sentido move-se intencionalmente para a família, prevendo que esse comportamento será incorporado ao longo do tempo tanto pela sua equipe como pelos outros membros da equipe multidisciplinar.

Motivada a melhorar a qualidade de assistência às famílias, a profissional da saúde retoma suas ações no cuidado à família com auxílio da equipe, a fim de certificar-se que o mesmo foi efetivo e que a equipe ficou satisfeita e se sentiu bem cuidada em suas necessidades.

A enfermeira faz continuas mudanças na equipe, estimulando a incorporação de suas ações no cuidado à família. 
ENT 1: "A gente é modelo. E os modelos bons e maus são imitados, não é? Então passei a imitar a funcionária [chamar a mãe pelo nome].Coisa que não fazia".

ENT 6: "... a enfermeira servir de exemplo para esses outros técnicos, os auxiliares de enfermagem, que compõem a equipe de enfermagem como um todo. $E$ eu me refiro à equipe de enfermagem...".

ENT 7: “... a equipe [de enfermagem] é o espelho do que o enfermeiro é".

ENT 5: "... é uma coisa que se constrói com a equipe, e eu acredito que a enfermeira seja o ícone, uma vez que ela é responsável por fazer a equipe trabalhar também com as famílias, porque uma andorinha não faz verão. Aqui a gente não trabalha sozinha, né? E se eu como enfermeira acolho as famílias, a minha equipe também irá acolhê-la".

ENT 7: “... senti isso a partir do momento em que a gente começou a trabalhar com o envolvimento da família no cuidado, e ainda estou longe do ponto em que pretendo chegar. Entretanto, já conseguimos perceber como mudou a conduta da equipe, já que ela é o espelho do que o enfermeiro é ponto. O primeiro passo da enfermeira é trabalhar com seu par, pra que se chegue no consenso do que precisa ser feito. O resto da equipe é o espelho do enfermeiro, a quem elevai ensinando por meio de suas atitudes, já que esse não é o tipo de coisa que se fala "ah, é assim, assim, assim.". Você tenta o novo modo e, procedendo dessa maneira, chega-se ao resultado. Todos notam que é algo positivo e começam também a mudar de comportamento. Hoje vejo quantos desentendimentos ocorriam e como deixaram de existir.É um evento raríssimo e muito difícil. É o que digo para a minha equipe. Quando estimulamos não há muitos elogios, pois lidar com pessoas é muito complexo. É muito mais comum que haja reclamação...".

\subsubsection{2 É preciso compreender a situação e a realidade da família}

Nesse conduta, a motivação da enfermeira no cuidado à família envolve não apenas conhecê-la, mas compreender sua situação e sua realidade, para que a assistência necessária àquela família possa ser realizada.

Dessa forma, a enfermeira se motiva no cuidado à família por meio de sentimentos relacionados com os próprios familiares, experiências vividas, conhecimentos teóricos adquiridos que vão sendo acessados ao longo do tempo e seu processo de amadurecimento.

No que diz respeito ao cuidado efetivo da família, a enfermeira entende que também precisa compreender a dinâmica familiar, em que a 
intenção não é solucionar o problema, mas clarificar para si mesma e para os familiares maneiras possíveis, a fim de resolver suas demandas.

ENT 2: "Na assistência à criança e ao adolescente, estamos sempre tentando compreender em que situação eles estão inseridos, como a família se organiza, quem são esses elementos e como essas relações se dão. Nossa intervenção está o tempo inteiro voltada para essas questões..."

ENT 10: "Geralmente as situações de estresse [da família] estão atreladas a um contexto fora daqui [do hospital], Vamos supor que a mãe esteja aqui com o bebê internado, mas tem outros filhos em casa, outras preocupações, ou então uma desestrutura familiar. Ela não possui, na maioria das vezes, o apoio esperado para aquela situação. Essa angústia de ficar dividida entre acompanhar [a gente percebe mais em relação à mãe] a criança aqui e cumprir as outras atividades a deixa preocupada. Percebemos, então, a existência dessa preocupação, muitas vezes atrelada a tantas outras coisas, as quais vamos notando durante a vivência cotidiana e as conversas..."

ENT 16: "Eu tento ver muito o lado de quem está ali acompanhando a situação da criança interna, da qual muitas vezes não se tem o diagnóstico. A gente vê a realidade da família, a tristeza que ela enfrenta ao ver o filho internado".

ENT 6: “... eu acho importante que a família seja bem recebida, que se pergunte como ela está. Muitas vezes ela adquire uma postura agressiva, porque no Pronto Socorro a porta está sempre aberta. Os familiares chegam agressivos e, se o profissional da saúde não tem a maturidade de tentar compreender esse comportamento, a resolução deixa de sertão boa quanto poderia. Portanto, perguntar o porquê daquela conduta, por que a família se comporta daquele jeito, acaba sendo uma tentativa de encontrar a melhor saída..."

ENT 4: "... quando a gente para pra tentar entender por que a mãe se porta daquela maneira começamos a questionar se por trás há alguma crença, algum valor ou alguma história familiar. Se a mãe se porta como uma superprotetora neurótica nos perguntamos se algo traumático já aconteceu. Tento entender para ajudar na medida do possível e tentar aumentar a qualidade de vida e de cuidado daquela criança..."

ENT 7: “... senti isso a partir do momento em que começamos a trabalhar com esse método, isto é, de envolver a família no cuidado. Ainda está longe de onde pretendo chegar, mas já pudemos perceber que, trabalhando isso, a equipe sofreu modificações, pois ela é o espelho do que o enfermeiro é. $O$ primeiro passo é, portanto, que a enfermeira trabalhe com seu par. Dessa maneira podem chegar no consenso almejado. O resto da equipe é o espelho do enfermeiro, o qual vai ensinando por meio de suas atitudes, já que essas lições não se tratam de algo que possa ser dito "ah é assim, assim, assim." Não. Tenta-se o novo modo, que repercute em você mesmo e nos outros, uma vez que demonstra resultados positivos. Os desentendimentos de outrora hoje não existem mais, ou são raríssimos. Procuro estimular a 
minha equipe, mas quando estimulamos os elogios não são freqüentes. Isso não é cultural. $O$ comum e que haja reclamações..."

\subsubsection{A família deve ser bem tratada}

A enfermeira tem consciência de que, quando ocorre a hospitalização de um filho, a família sofre um impacto que a deixa vulnerável.

Por isso ela sabe que, ao se aproximar da família como unidade a ser cuidada, não deve esperar apenas o reconhecimento por parte dela. Seu objetivo é que os familiares compreendam que ela tem o conhecimento de que aquela situação afeta a todos eles e de que existe uma motivação consciente e contínua direcionada para o cuidado à família.

Essas circunstâncias fazem com que a enfermeira se motive no cuidado à família sem julgá-la, uma vez que compreende sua fragilidade. Tenta, portanto, acolhê-los e ouvi-los durante o atendimento.

ENT 16: "Acho que tem que ser muito bem tratado e muito bem cuidado. É muito importante que se veja o lado de quem está acompanhando, seja mãe, pai, avó ou cuidador..."

ENT 10: "Em qualquer lugar que estejamos, queremos em primeiro lugar ser bem cuidados, bem tratados nas questões básicas como entrar desejando um bom dia, conversar, dar um pouco de atenção, tentar amenizar o que puder."

\subsubsection{4 É preciso pensar na família em qualquer setor}

A motivação da enfermeira no cuidado incluindo a família, independe do setor ou da população a que assiste.

Sendo assim, a enfermeira pensa na família não só no âmbito da pediatria, mas também em outros segmentos hospitalares. Essa motivação parte da vivência pessoal, ou situação biográfica, com um familiar doente, em que a necessidade de ser ou ter sido cuidado direciona no presente seu olhar para a esfera profissional.

A enfermeira alia a essa ideia a crença de que a criança necessita relacionar-se e manter ao máximo a sua rotina preservada, o que inclui 
também as pessoas significativas, de maneira que o cuidado à família se dê de forma a construir uma relação de cumplicidade entre ambos.

ENT 4: "Eu acho que não apenas a pediatria deveria ser levada em conta. Em nenhum lugar o ser humano vive sozinho, e por isso, quando você cuida de uma pessoa, seja ela uma criança ou um adulto, não há como simplesmente olhar para ela de maneira isolada...".

ENT 15: "Acho que independente de ser criança ou não, é preciso pensar na família também...".

Ent 5 "Até tive algumas experiências com adultos, nas quais não é muito observado esse aspecto da família. Creio que esse olhar ainda seja mais forte na pediatria. Espero, entretanto, que seja estendido...".

\subsubsection{Preocupar-se com os outros, inclusive com a família}

Assim como a enfermeira pensa e se interessa pelo bem estar do outro, esse sentimento a motiva a exercê-lo também no cotidiano hospitalar no que diz respeito ao cuidado à família, favorecendo o relacionamento entre ambos e a assistência que for necessária para os familiares.

Outro fator que estimula a enfermeira ao cuidado à família é a influência que a educação exerce na relação com o outro e sua importante ligação entre elas.

ENT 6: “... creio que a questão de educação e valores também implica um pouco, porque quando olho para mim vejo que sou uma pessoa muito preocupada. Fora do ambiente da assistência á sou assim, me preocupo com o próximo, com seu bem-estar e procuro saber se está tudo bem com ele. Essa conduta acaba repercutindo no contexto da assistência...".

\subsubsection{Colocar-se no lugar do familiar}

No cuidado à família da criança hospitalizada, a enfermeira coloca-se no lugar dos familiares por meio de sentimentos revividos por ela com sua própria família, tais como medo, insegurança e angústia.

Esses sentimentos despertam na enfermeira a vontade de se aproximar da experiência da família, conseguindo assim perceber a 
assistência necessária pela ótica dos familiares sem que o seu próprio julgamento interfira nas decisões (empatia).

Dessa forma, a enfermeira une a bagagem técnica à sua sensibilidade em colocar-se no lugar da família, e esses fatores corroborarão conjuntamente para o aumento da qualidade da assistência que prestada. Com isso, percebe que ocorre não apenas a sua mobilização em relação à família, mas também a mobilização da família em relação à enfermeira, na medida em que a vivência de ambos propicia a aproximação e estreitamento de vínculos.

ENT 3: "... às vezes me coloco muito no lugar da família...", “... é claro que no inicio, assim quando a criança é internada, toda a tenção acaba se voltando para ela, visto que faz-se necessário cuidar dela e ver do que ela precisa., Nesse momento chegamos aos pais e pedimos para que aguardem um pouco. Após os cuidados à criança vamos conversar com eles. Como já tive familiares internados, acabo por entender o que esses parentes sentem. O sentimento deve ser ainda mais forte quando se trata do pai e da mãe da criança."

ENT 1: “... é uma questão de se colocar no lugar do outro...”.

ENT 13: "Porque muitas vezes, ao nos colocarmos no lugar do outro, mexemos com conteúdos internos nossos. Isso faz com que tenhamos dificuldade de enfrentar algumas situações".

ENT 12: "... a gente tem que tentar se colocar no lugar da pessoa, saber que ela está passando por um momento mais sensível...".

ENT 11: “... então se você se coloca no lugar, você começa a ter uma sensibilidade a mais, uma visão diferente disso...".

ENT 12: "... eu acho que a gente tem que tentar compreender isso (há mães que embora saibam que o bebê está aqui só para tomar um banho de luz e que se trata de uma coisa fisiológica, ficam estressadas como se fosse algo grave ), saber se colocar no lugar do outro e tentar entender que aquele momento realmente é difícil, é de crise...".

ENT 16: “... eu sempre fui assim. Posso dizer que isso é uma coisa minha, independente da pessoa estar aqui internada, estar no hospital, fora de casa ou fora do ambiente hospitalar. Ajo assim com as pessoas. Faço da forma como gostaria que fizessem comigo."

ENT 15: "A gente tem que se colocar no lugar dela e entender que ela está há um ano dentro do hospital. Devemos questionar se estaríamos melhor do que ela caso estivéssemos nas mesmas circunstâncias." 


\subsubsection{Comparar com sua própria família}

No cuidado à família a enfermeira aproxima-se do contexto que ela está vivenciando e, ao observar a situação, compara-o com sua própria, o que traz uma reflexão da realidade que pode vivenciar ou já vivenciou.

Essa atitude gera uma motivação em suas ações, fazendo com que se aproxime da família numa relação face a face e intersubjetiva, compreendendo que os familiares ficam mais sensíveis diante do sofrimento causado pela doença da criança.

ENT 3: “... então às vezes eu tento imaginar uma criança como se fosse, vamos supor, meu sobrinho... e sofro junto com ela até que melhore..."

ENT 13: "Me sinto muito bem. Creio que se eu tivesse um filho internado, esperaria esse acolhimento. Então eu acho importante dar aquilo que você acredita como valor, como o respeito, a compreensão e a empatia com a pessoa que está passando por um momento delicado da vida. Isso deve ocorrer mesmo quando se trata apenas de uma bronquitezinha fácil de resolver. Como já falei antes, a vida lá fora fica parada, então você tem sempre uma grande preocupação, e dentro de uma UTI essa preocupação é muito maior, porque só a palavra já assusta. Temos muitas experiências de conversas com mães, nas quais elas dizem que ao chegar aqui tomam um susto absurdo. Depois percebem que estar na UTI é algo positivo, porque o cuidado é intensivo. Algumas delas até já disseram que, caso houvesse outra necessidade de internação, gostariam que fosse na UTI, já que aqui nós estamos presentes a todo momento. Isso é bacana de se ouvir, porque desfaz aquele trauma associado à UTI e ao estado grave. Constata o reconhecimento de que o cuidado intensivo prestado na unidade é bom."

ENT 11: "Eu acho que, me colocando no lugar, eu gostaria de ser tratada dessa forma caso precisasse. Quando nos colocamos no lugar das mães de crianças crônicas - visto que aqui temos muitos casos como, muitas reinternações - pensamos "puxa vida, que batalhadora!". Tem muita gente que diz que a mãe é folgada, a mãe isso, a mãe aquilo, vai embora e deixa a criança aqui. Eu, entretanto, tento pensar no tanto de coisas que ela tem para fazer. Afinal, além de mãe ela é dona de casa ou tem uma profissão, o que faz com que seja difícil de acompanhar a rotina do hospital. Tive um momento em que fui acompanhante do meu irmão numa cirurgia eletiva e fiquei seis dias com ele. Eu quase enlouqueci. Imagino essas mães crônicas que ficam dois meses, dois anos aqui no hospital. 
PROPOSIÇÃO 2: Encontrar junto com a família maneiras de promover o enfrentamento e as possíveis resoluções de suas necessidades na situação de doença.

\section{SUBCATEGORIA:}

\subsubsection{Atender às demandas da família}

A enfermeira, no cuidado que inclui a família, acolhe suas necessidades na tentativa de direcionar e auxiliar na sua resolução por meio dos próprios familiares. Por isso, a enfermeira tem a compreensão de que a situação é vivenciada pela família, a qual tem o direito de se manifestar do jeito que the é possível naquele momento. A profissional não utiliza julgamentos de valor, e sua intenção se torna clara no instante em que os familiares se sentem ouvidos e acolhidos em sua necessidade. Essa conduta faz com que a enfermeira se torne referência no caso de eventuais retornos da criança ao hospital.

A enfermeira compreende o impacto que a hospitalização tem sobre a família, o que gera nela a necessidade de dar assistência para promover um reajustamento familiar, o que facilita o enfrentamento do processo de internação do filho.

\subsubsection{Resolver as questões da criança e de sua família}

Para a enfermeira, incluir a família no cuidado pode resolver tanto suas questões como as da criança, tendo como motivação a resolução que deve ser compartilhada com os parentes, visto que são os maiores conhecedores do paciente internado. A família pode subsidiar as melhores e menos invasivas intervenções com a criança, trazendo maior conforto para ambos.

Para a enfermeira, que percebe a família como unidade de cuidado, resolver o problema da criança não é o bastante, visto que está inserida numa família.

Em função disso, ela amplia seu foco de atenção às questões de toda a família, por saber que prover cuidado a ela significa cuidar da criança. 
ENT 6: "Eu pretendo duas coisas: resolver a questão da criança naquele momento, porque ela ta doente, num Pronto Socorro, e eu preciso resolver aquela questão da doença, que é tratar a criança. $E$ abordar a família nas questões emergenciais, no momento em que ela mais precisa."

\subsubsection{Integrar a família no cuidado}

O cuidado à criança pode ser tornar uma parceria entre a família e a enfermeira, o que passa a ser uma motivação estratégica para que haja um ajuste às novas rotinas hospitalares, já instituídas com o intuito de minimizar os possíveis efeitos negativos para a criança e os familiares e possibilitar o cuidado..

Dessa forma, a enfermeria acredita que a família sente-se exercendo seu papel perante a criança em situação de doença e, intercedendo por seu filho, torna-se mais segura, o que facilita a relação entre todas as partes e estreita os vínculos que estão sendo estabelecidos ao longo do tempo em que a família fica na unidade hospitalar.

A enfermeira motiva-se a cuidar da família para ter qualidade na assistência e trazer benefícios a todos os envolvidos, incluindo toda a equipe.

ENT 7: “... você vai trabalhar da forma que não é apenas o melhor para você, mas o melhor para todos. Assim vai efetivamente conseguir causar impacto e a família vai se aproximar de você. Acho que esse tipo de mudança traz coisas positivas. Erradica-se a hierarquia e todos ficam no mesmo patamar. Passa-se então a entender outras coisas, como o fato da família procurar o enfermeiro e não o médico. Ela vem com queixas e perguntas, e o enfermeiro sabe que essas questões devem ser tratadas com o médico. Como os enfermeiros passam mais tempo à disposição dos familiares e pacientes, é a eles que os envolvidos acabam recorrendo. $E$ isso denota, de certa maneira, o reconhecimento de nossa função, além de causar impacto no melhor cuidado à criança..."

ENT 5: “... eu acho que a gente vai moldando o nosso perfil para trabalhar com crianças e suas famílias... E essa relação se constrói. Há patologias crônicas que sempre voltam, então a gente também cria um vínculo, uma vez que se trata de um setor onde não conseguimos dar um seguimento àquele planejamento de cuidar da família. É um período curto, porém no qual há muito que se fazer..." 
ENT 13: "Normalmente nós os convidamos a participar do cuidado."

ENT 11: "Eu gosto muito de inserir a família no cuidado, por meio de conversas com as mães e incentivando-as a ir ao berçário.

\subsubsection{Reconhecer a família}

A enfermeira se motiva a conhecer a família para que ao distinguir os membros saiba quem é a pessoa mais significativa para a criança e quem mais sofre na experiência. Procura identificar as necessidades que a família possui e quais os meios disponíveis para lidar com a advento de doença da criança, para que a partir daí possam ser sugeridas maneiras efetivas de lidar com a situação.

A partir desse reconhecimento a enfermeira cuida da família por meio de elogios às capacidades que os familiares demonstram em lidar com a situação. Ela percebee que isso faz com que os pais, em especial, vejam-se em condições de pensar em soluções, a fim de enfrentar a situação de hospitalização da criança.

ENT 5: "Eu tento atribuir muitos méritos à mãe, dizendo como foi bom ela ter trazido o filho ao hospital."

\subsubsection{Acolher a familia}

A enfermeira norteia suas ações de cuidado promovendo o acolhimento à família, por reconhecer o impacto causado pela hospitalização da criança e, por conseguinte, o aumento da sua sensibilidade.

Tendo consciência da importância do acolhimento, a enfermeira motiva-se e passa a utilizar esse recurso como forma de iniciar um vínculo positivo com a família, bem como acessar as maneiras que ela possui para resolver as suas necessidades.

ENT 6: “... eu observo que você tem que acolher essa família, que é muito importante o acolhimento..."

ENT 5: "Eu pretendo sempre acolhê-los, atendê-los dentro dos limites das minhas atribuições como enfermeira." 


\subsubsection{Informar a família}

A enfermeira utiliza a informação à família como forma de cuidar dela para que esteja ciente de tudo o que está acontecendo com a criança. É uma forma de estabelecer parceria com os familiares e começar a acessar suas habilidades de tomar decisões, além de ser também uma maneira de amenizar o sofrimento do restante da família que porventura não esteja presente no ambiente hospitalar naquele momento.

A enfermeira também utiliza as informações como motivação para estreitar vínculos e promover segurança e confiança da família.

Através de suas experiências vividas, percebe que manter a família informada reduz o stress causado pela doença da criança e também minimiza o sofrimento do próprio paciente.

ENT 3: “... eu tento deixá-los sempre a par da situação da criança, para que não fiquem desinformados, uma vez que o sofrimento já é grande. Vejo então se consigo amenizar um pouquinho mais o sofrimento dos pais aqui. Eu sei que eu não posso tirar aquele sofrimento, mas tento fazê-los entender que a criança está sendo bem tratada, explicando o que posso. Faço o possível para deixálos a par dos cuidados que estão sendo feitos..."

ENT 7: "Acredito até que o tempo de cura é mais curto quando a família está presente. Porém o papel do profissional influencia nisso. Acredito que dessa maneira fica mais menos penoso para a família e menos traumatizante para a criança. É um tipo de abordagem que faz com que a família não se sinta excluída do cuidado."

ENT 13: "Então a gente procura sempre explicar tudo o que está acontecendo, tirando todas as dúvidas e deixando-os bem à vontade."

ENT 8: "Sendo informada de todas as condições do seu filho e dos procedimentos que serão realizados." 
PROPOSIÇÃO 3: Aprimorar a abordagem à família para apropriá-la do cuidado ao seu filho.

\section{SUBCATEGORIA:}

\subsubsection{Aprimorar a abordagem à família}

Motivada a realizar o cuidado à família de forma mais elaborada e efetiva, a enfermeira busca aperfeiçoar-se continuamente, a fim de que essa abordagem seja incorporada pela sua equipe e posteriormente pela unidade como um todo.

Dessa forma, todas as ações futuras que a enfermeira programará serão no sentido de obter condições para melhorar o cuidado dessa família.

Ela se vale de construtos teóricos, de sua experiência vivida e de sua bagagem de conhecimentos para programar melhorias nessa abordagem à família.

Diante das motivações em aperfeiçoar o cuidado à família, a enfermeira se vale também da crença de que o aculturamento é um processo que ocorre a longo prazo, e que ela necessita estar em constante movimento em prol dessa forma de cuidado à criança e à família.

\subsubsection{Criar um ambiente favorável à família}

Com o propósito de melhorar a abordagem à família, a enfermeira vai promovendo mudanças dentro da unidade, que sejam compatíveis com esse foco de cuidado, a fim de que o ambiente se torne cada vez mais favorável à família que está sendo atendida junto à criança.

O ambiente que motiva a enfermeira no cuidado à família não está vinculado somente às disposições físicas que a unidade oferece, mas também à forma emocional de que se utiliza para lidar com ela, fazendo com que se sinta acolhida e compreendida em suas necessidades. 


\subsection{Mudar a forma de atender}

A forma como a enfermeira cuida dos familiares da criança doente é um fator ambiental emocional de relevância, e que portanto deve ser observado por ela. A abordagem modifica o comportamento da família que é recepcionada na unidade, a qual deve ter uma equipe apta a the proporcionar um ambiente acolhedor.

Dessa forma, a enfermeira é impelida a modificar a forma de atender a família, uma vez que entende que frente ao impacto da hospitalização do filho e do estresse que esse evento causa, podem ocorrer comportamentos de sofrimento e não enfrentamento da situação.

ENT 1: “... é esse o perfil que deve ter alguém que se propõe a trabalhar num Pronto socorro Infantil, não é? Você vai trabalhar com pais que vão te xingar, com mães desesperadas, com mães que vão até te bater se você não atendê-la. São consequências do desespero. É O DESESPERO. É esse o perfil, e você não vai responder, não vai brigar, não vai discutir, porque você é um profissional. É preciso agir de forma profissional, respondendo àquilo que ela está te pedindo. Agora eu falo, tem gente que tem esse lado profissional, mas tem um plus, sabe? Tem um plus, nasceu para a área, acolhe. Você vai ver que tem em alguns plantões, em determinados plantões que eles falam como se estivessem pegando no colo. E eu penso "que coisa boa!"

ENT 1: “... vocês podem resolver isso, né? Porque a alta depende de vocês e a explicação do porquê de ele ainda estar aqui também. Várias vezes eu já fiz isso. Mas agora, quando chamo é uma só vez. Aí vem responde porque eu não fico ligando lá no conforto não, dá pra atender, que, que é isso? Tinha que ta lá, né? Tinha que ta lá junto. Então, é em relação a essas coisas, você vê que assistente não fica no conforto mais, né? Então, essas coisas vão mudando, vão mudando. Então, essas coisas a gente vai mudando e muda todo mundo, né? Inclusive a outra equipe, a postura, a forma de atender sabe? A forma de atender. Olha, tem coisas que são inadmissíveis. Eu não deixo maltratar, não deixo tratar mal não. Viro uma fera, e olha, eu já briguei muito..."

ENT 1: “... a definição de papéis é muito importante, porque clarifica essas coisas, inclusive no nosso âmbito. O que é nosso, afinal de contas? É de cuidado que ela está precisando? Então o cuidado também cabe a nós, tanto é que há coisas muito bem definidas. Às vezes a consulta médica é interrompida e uma ou mais enfermeiras são chamadas para avaliar situações, como uma ferida, por exemplo..."

ENT 1: “... e assim você delimita até onde pode ir e até onde o profissional pode ir. Dessa maneira assim a gente define bem os papeis e, fazendo isso, a mãe passa a saber a quem deve recorrer no momento de reivindicar alguma coisa. Pode ser também um 
pai, mas na maioria das vezes é a mãe. Ela vem para ser atendida aqui, portanto em sua próxima vinda já saberá qual é a dinâmica. Identificará os profissionais pelo uniforme. Se está de jaleco é medico, e se usa colete é enfermeira..."

\subsection{Preocupar-se com a família}

A visão que a enfermeira tem acerca da família com a qual está lidando também a motiva a aprimorar o cuidado que oferece.

Ela percebe que a família fica fragilizada frente à hospitalização da criança.Por isso, preocupa-se com os familiares e entende que a abordagem é movida por sua bagagem de conhecimentos e pela experiência pessoal que vai acumulando, dissociando assim o julgamento moral ou de qualquer ordem por parte da equipe que está incumbida dos cuidados, visto que na experiência de doença cada família e cada membro nela inserido refletem o impacto da experiência de uma forma diferente.

Assim sendo, mesmo que a enfermeira relembre sua experiência pessoal de doença e hospitalização, ela tem a consciência de que aquela circunstância não é sua, e sim da família. Preocupando-se e ao mesmo tempo dissociando-se do núcleo familiar ela pode oferecer uma perspectiva diferente daquela que possuem os familiares que vivenciam um momento de fragilidade.

ENT 5: “... porque a gente estava atendendo a criança e imaginando onde estariam os pais e se sabiam o que estava acontecendo com seu filho..."

ENT 16: “... a partir do momento em que a criança é internada eu tento ver o lado de quem está ali acompanhando a situação. Por vezes, quando o diagnóstico ainda é desconhecido, presenciamos as incertezas e a tristeza da família ao ter que ver o filho internado..."

\subsubsection{Fortalecer a família}

Existe uma motivação da enfermeira em fortalecer a família que vivencia a doença da criança, a fim de que ela tenha condições de atender às suas próprias necessidades e assim garantir o seu funcionamento pleno mesmo depois da hospita, ou seja, no futuro. 
Assim sendo, a enfermeira considera que cabe a ela oferecer condições para que a família consiga se fortalecer, o que a mantém estimulada a cuidar da família com empatia, compaixão, respeito àquela vivência e sem pré-julgamentos.

\subsection{Compreender a situação da família}

Com o intuito de fortalecer a família, a enfermeira vale-se da tentativa de compreender a situação pela qual ela passa. Desse modo, passa a pensar em estratégias para assisti-la naquele momento e que tenham repercussão na dinâmica familiar.

ENT 11: "Muitas vezes a pediatria ensina mães de crianças cardiopatas que nunca tinham dado banho na criança mesmo após seus oito meses de vida. Pergunto se querem aprender e tento estimulá-las a dar banho em seus bebês, na medida do possível. Obviamente não as deixo medicá-los ou fazer qualquer outra coisa que não esteja ao seu alcance. Mas em certa medida as deixo participar e explico muitas coisas. Eu tenho um pouco dessa didática, gosto de explicar, de ensinar, e então tento explicar o que esta acontecendo com uma linguagem que entendam. Acho que explicando e incentivando-as ao cuidado, faço com que se sintam inseridas.

ENT 2: "Na assistência à criança e ao adolescente a gente está sempre tentando compreender onde essa criança está inserida, como a família se organiza, quem são esses elementos e como essas relações se dão. A nossa intervenção é o tempo inteiro é voltada a essas questões..."

ENT 10: "Geralmente as situações de estresse [da família] estão atreladas a um contexto fora daqui [do hospital]. São situações, vamos supor, em que a mãe está aqui com o bebê internado, mas tem outros filhos em casa e outras preocupações, ou então uma desestrutura familiar. Ela não tem o apoio esperado para aquela situação e, na maioria das vezes, ficar dividida entre acompanhar [a gente percebe mais em relação à mãe] a criança e as outras atividades a deixa angustiada. Então a gente vê, conforme vai vivenciando e conversando, que essa preocupação existe..."

ENT 15: "É aquela tal coisa: às vezes a mãe age de tal forma, às vezes é até um pouco agressiva, mas você não sabe o que está acontecendo na vida dela. Talvez se você chegar e conversar um pouco vai entender o porquê de seu comportamento." 


\subsection{Conhecer a experiência da família}

Dessa forma, a enfermeira também se utiliza do recurso de conhecer a experiência da família para que possa pensar em assisti-la, bem como fazer com que se fortaleça e possa exercer seu direito de ser família mesmo durante a hospitalização de um de seus membros.

ENT 2: “... qualquer abordagem que utilizamos é no intuito de compreender a questão da, de saber onde essa criança está inserida e como a família se organiza. Questionamos quem são esses elementos e como essas relações se dão..."

ENT 1: “... olha, a mãe não é boba. Ela também tem que falar, já que o filho é dela. A mulher passa a reivindicar o direito que é dela, não é? Enquanto ela não conhece seus direitos a gente tem que desempenhar esse papel. Somos um pouco advogados, pois fazemos o intermédio. E eu faço isso mesmo. Dou a cara a tapa..."

ENT 10: "Olha, eu me sinto assim muitas vezes: faço aquilo que está ao seu alcance. Por vezes vemos, no dia a dia, que pequenas coisas - como pequenos gestos e conversas que tentem esclarecer o que está acontecendo com o paciente - podem amenizar um pouco a angústia dos familiares da criança internada. Ouvir um pouquinho aquela mãe que está passando por um momento de estresse também pode ajudar. É difícil de explicar. A gente tenta trabalhar conforme cada situação. Algumas são mais tranquilas e só exigem o apoio ali naquele momento, diariamente. Mas há também situações em que se necessita da ajuda de outros profissionais. São coisas com as quais lidamos em nossa profissão."

\subsubsection{Incorporar novos modos de ser com a família}

A enfermeira, compreendendo que a família é essencial no cuidado à criança hospitalizada, incorpora elementos que a motivam a aproximar-se cada vez mais dos membros da família, o que favorece a formação de vínculos e mais uma vez serve de modelo para o restante da equipe. Essas ações são um motivo para substituir gradativamente antigos modos de tratamento da família por modelos mais adequados de abordagem, o que inclui chamar os familiares e a criança pelos nomes, apresentar-se e garantir o entendimento da família quanto aos papéis que cada profissional desempenha no processo de doença da criança. 
ENT 14: “... apresento-me sempre dizendo meu nome. Deixo claro que para qualquer coisa a família pode vir falar comigo e me perguntar caso tenha alguma dúvida. Explico que no início a preocupação é grande e o entendimento é escasso, mas que conforme for pode me perguntar..."

ENT 10: "... eu penso que independente de onde estamos, o que queremos é ser bem cuidados, bem tratados. Penso em coisas básicas, como desejar bom dia ao entrar, conversar, dar um pouco de atenção...

"ENT 1: "... Apresenta-se, eu sou a enfermeira vou ficar nesse plantão, eu vejo as meninas fazendo isso, coisa que não fazia há nove anos...".

ENT 1: "... essa coisa de tratar por mãezinha... Alguns ainda têm esse resquício, mas a maioria já trata a mãe pelo nome. Não é mãezinha, não é vozinha, não é tia. A mãe deve ser tratada pelo nome. Eu estranho que digam mãezinha pra mim. Eu falo, mas sou mãe dos meus filhos. Então é uma questão de respeito perguntar coisas como "A senhora é que é a dona fulana? A senhora é o que do paciente? A criança tem apelido? Quer que a chame pelo apelido?"

\subsubsection{Manter e progredir a visão sobre a família}

A conduta motivacional da enfermeira que tem a família como sendo fundamental no cuidado pediátrico possui como propósito cultivar e prosseguir no cuidado aos familiares e fazer com que essa conduta gere uma aculturação para a equipe multidisciplinar.

ENT 13: "Até durante a melhora da criança, até na própria convivência, na satisfação pessoal e profissional da gente e do pessoal, de quem tem o filho internado, dos médicos, o ambiente acaba se tornando calmo, de convivência tranquila, onde tudo é muito claro, as coisas são muito bem esclarecidas. Não há dúvida a respeito de nada, inclusive quando a gente tem criança muito grave e sabe que está prestes a morrer as famílias são informada, e ficam presentes o tempo todo. A gente fica junto o tempo todo, portanto acho que isso ajuda na evolução e na tranquilidade de todos."

\subsection{Ampliar o conhecimento}

Direcionar-se na ampliação do conhecimento motiva a enfermeira a buscar constantemente o aprimoramento cientifico e o amadurecimento pessoal e profissional a fim de desempenhar com competência o cuidado à família. 
Dessa forma, ela acessa recursos que vão permitir assistir às famílias de modo cada vez mais efetivo, sabendo que esse conhecimento é dinâmico e que como tal precisa ser continuamente buscado e reavaliado.

ENT 14: "Não é de repente, você não vai, você vê que às vezes a família conversa mais com outra enfermeira do que com você. Então você se pergunta por quê. Mas tudo teve um tempo. Não é no primeiro dia que a mãe vai falar um monte de coisas para você. Isso se dá com o tempo, e uma das coisas foi o curso (de família na EEUSP), que me ajudou bastante."

ENT 6: “... então não consigo ter esse tipo de abordagem. A minha abordagem é mais ligada às questões e necessidades imediatas da criança e da família..."

ENT 9: "... acho que esse olhar de envolver a familia vem desde a formação da graduação. A gente já começa a desenvolver isso no dia a dia, pois vamos conseguindo perceber algumas coisas que antes ignorávamos, mesmo em relação aos problemas. Passamos a ter uma visão um pouco mais ampla..."

ENT 12: "Eu acho que vai da sensibilidade de cada um. Mas um pouco vem também das aulas de graduação. O que a gente mais aprende sobre empatia é o tentar se colocar no lugar do outro para entender um pouco do que ele está passando e poder cuidar melhor..."

ENT 13: "Desde que entrei na faculdade, desde que comecei a trabalhar - eu estou formada há 26 anos - eu acho que as vivencias vão mostrando coisas. Tenho uma bagagem grande de vida, e algumas vezes eu tive meu pai, minha mãe e meu irmão internados. Então acabei vivenciando algumas coisas. Além disso, o fato de acompanhar muitas famílias e crianças ao longo de 26 anos me ensinou a ver a coisa de outro jeito, e esse aprendizado que não é só teórico não - é uma coisa interna mesmo. Você tem essa predisposição, então eu acho que é um misto de várias coisas, tais como tempo de formação, tempo de vida, de predisposição para entender, para enxergar, de vivências com a própria família e de interação com os próprios pacientes. Eu tenho uma coisa diferente, pois quando eu me formei, em 1985 - e a minha primeira especialização foi enfermagem psiquiátrica - eu trabalhei com enfermagem pediátrica durante 7 anos. Sempre fiz coisas relacionadas à psicologia e à psiquiatria, então sempre tive um foco diferente. Acho que isso contribuiu muito para que eu visse as coisas de outra forma. Foi uma parte da minha vivência que agregou muitos valores e muitos entendimentos a respeito do ser humano como um todo. Me lembro de um paciente da época em que comecei a trabalhar num hospital. Na entrevista de admissão a enfermeira me perguntou o que eu achava da família do paciente, e eu respondi que achava tudo. Ela então replicou "Como assim tudo?" Eu falei que eram tudo porque só emprestam o paciente para a gente durante um período, e depois são eles que cuidam dele. Por isso temos que prepará-los. Naquele momento ela disse que eu estava empregada. Eu achei graça, pois é uma coisa em que eu acredito mesmo, não falei para fazer graça nem para ganhar pontos. E é verdade, os pacientes não são 
nossos, e sim da família. Estão apenas emprestados aqui e temos que cuidar deles da melhor maneira possível."

ENT 9: "Aqui é um setor de cuidado. Não tem pra onde fugir. A família está envolvida, e esse olhar de envolvê-la já vem desde a graduação. Ali a gente já começa a desenvolver isso, mas é claro que no dia a dia vamos conseguindo perceber algumas coisas que antes eram ignoradas. Até mesmo em relação aos problemas passamos a ter uma visão um pouco mais ampla, uma vez que tentamos evitar essa questão de julgar logo no inicio uma situação. Evitamos entender o lado da mãe, o lado da família e o que esta acontecendo. Às vezes parece que a mãe não vem por não estar envolvida com a criança ou por estar negando o ocorrido. Mas muitas vezes a gente não consegue perceber o que esta por trás desse comportamento, e por isso a experiência do dia a dia é positiva. Por meio dela a gente começa a ver novas coisas, porque a princípio existe a tendência a um pré-julgamento, mesmo da família. Quando a família é presente e está se envolvendo, aparentemente tudo está bem, a gente acaba só acompanhando e orientando. Mas quando tem um problema - e a tendência é isso acontecer, mesmo que a gente tente evitar precisamos tentar entender o lado da família do bebê que está internado. Para a mãe é muito difícil ter sua criança internada logo após o nascimento. Os bebês ficam meses prematuros aqui. Tem um que já está há três meses internado, e já temos uma bagagem. Com o dia a dia isso vai mudando."

\subsection{ENGAJAR A FAMÍLIA}

Engajar a família é outra conduta motivacional de cuidado da enfermeira, guiada pelo desejo de melhora da criança e de como ela será cuidada pela família, constituindo assim os focos de ação da enfermeira no sentido de se voltar para aliviar e/ou minimizar o sofrimento da criança diante da experiência de doença.

Nesse sentido, toda ação executada pela enfermeira é voltada à criança, sabendo que a família exerce um papel importante nesse contexto, a fim de atender às necessidades do paciente.

Assim sendo por meio de sua bagagem de conhecimentos adquiridos, a profissional se sente responsável pela integridade física e emocional da criança a partir daquela experiência de doença.

Apesar das famílias estarem presentes no ambiente, na percepção da enfermeira elas aparecem sempre vinculadas às crianças.

Nessa perspectiva, todas as ações da enfermeira visam o bem-estar da criança no presente e no futuro. Por isso ela chega a reconhecer que em 
alguns momentos a família não recebe a atenção adequada às suas necessidades.

Para a enfermeira, nessa conduta motivacional, o cuidado à família é importante e suas ações visam capacitar os membros a prestar o melhor cuidado à criança sob sua ótica, e não a partir das necessidades referidas pelos familiares.

Nesse sentido, os construtos utilizados pela enfermeira são acessados por meio das crenças e valores individuais sobre como cuidar da família e como cuidar da criança.

Existe uma linha tênue entre a definição de papéis da enfermeira e da família na medida em que o vínculo se estabelece, e a quebra desse limite gera confusão para ambas as partes.

Por isso, a enfermeira se engaja na construção de ferramentas que Ihe possibilitem clarificar os papéis, estabelecer o vínculo e conferir e confiar à família o poder de suprir suas demandas, auxiliando-a a capacitá-la para tal.

PROPOSIÇÃo 1. Engajar a família no cuidado é importante para o restabelecimento da criança.

\section{SUBCATEGORIA:}

\subsubsection{A presença da família é importante}

A enfermeira reconhece que a família é importante no processo de doença do paciente e se motiva para engajar a família na medida em que se dispõe para o cuidado á criança e em suas necessidades, fazendo com que os familiares se aproximem e estabelecendo um vínculo com eles.

Sentindo-se responsável pela criança durante a sua hospitalização, a enfermeira considera a família como parte importante no processo de recuparação da criança, bem como instrumento para a manutenção da saúde após a experiência de hospitalizaçào e de doença.

A família também é inserida pela enfermeira no cuidado à criança hospitalizada, motivada fortememte pela filosofia da instituição, que estabelece que a família permaneça 24 horas com a criança. 


\subsubsection{Apreciar a presença da família}

Como se sente responsável pelo bem-estar da criança hospitalizada, a enfermeira motiva-se no cuidado por apreciar a presença da família na unidade. Esse fator facilita a formação de vínculos com a criança e com os próprios familiares, além de contribuir para a melhora do paciente, visto que se sente segura na presença dos parentes.

A enfermeira engaja a família por sentir que a mesma encontra-se fragilizada, e nesse sentido percebe a importância da família estar junto à criança, minimizando o sofrimento.

A enfermeira considera a presença da família por sentir que ela é importante para a criança. Entretanto, mesmo considerando a família importante no processo de doença da criança e estando estimulada, ela não tem clareza do seu papel no cuidado aos familiares.

ENT 15: "Acho que a família é uma parte muito importante, porque ela sofre junto com a criança que está doente."

ENT 9: "Eu sinto que é importante que o enfermeiro esteja perto da família. É importante ficar próximo, ajudar e cuidar. Tudo isso faz diferença para eles, mesmo depois da alta."

ENT 13: "Então a gente até gosta da presença deles, que é muito importante. Eu acho que a convivência é bem tranquila, a não ser quando se trata de uma pessoa mais problemática, cheia de crises e angústias. Nesse caso a gente tem que ser um pouquinho mais psicólogo do que enfermeira. É bem por aí."

\subsubsection{Falta tempo para atender a família}

Em alguns momentos a enfermeira, mesmo motivada, reconhece que não tem tempo para atender a família como deveria, uma vez que a prioridade está no cuidado à criança.

Em função disso, a família torna-se coadjuvante no processo de trabalho da enfermeira.

ENT 14: “... é uma coisa que eu gosto. Mas aqui na UTI falta um pouco de tempo. Então eu tento na medida do possível dar muita atenção, principalmente quando a criança está sendo internada. 
No momento em que a mãe chega eu gosto de saber do que a criança precisa com urgência..."

ENT 15: "Olha, eu acho que às vezes é um pouco corrido e por isso não há muito tempo para conversar."

ENT 15: "De repente já passou por não sei quantos hospitais, não teve o problema resolvido, ninguém diagnosticou nada, então a falta de tempo às vezes atrapalha um pouco, porque aqui o trabalho costuma ser corrido."

A enfermeira, por ter como foco o cuidado à criança, em alguns momentos se sente contrariada na abordagem à família. Isso se dá pela falta do tempo que a enfermeira julga necessário para se aproximar da família. Esse comportamento gera uma reflexão posterior, pois ela reconhece a necessidade dos familiares e o fato de não conseguir atendê-la plenamente.

ENT 14: “... às vezes eu sinto que poderia fazer mais. Há dias em que, quando estou vindo para cá, percebo que estou meio impaciente. Tem períodos em que a gente está mais estressada, e quando a mãe pede alguma coisa ficamos de saco cheio, porque tem muita coisa para fazer, o plantão esta acabando, você tem que terminar e não consegue dar atenção para aquela pessoa. Nesses casos saímos um pouco frustradas por não ter dado essa atenção. E em alguns casos nem é por falta de tempo, e sim por cansaço do trabalho. Acabamos ficando irritadas e não sendo tão atenciosas..."

\subsubsection{Aproveitar qualquer oportunidade para orientar a família}

Como a enfermeira se sente motivada pela responsabilidade que possui sobre a criança, sua ação é destinada a capacitar a família a desempenhar $\mathrm{o}$ atendimento mais adequado possível. A enfermeira sabe qual deve ser o procedimento, e o faz por meio de orientações à família sobre a melhor forma de cuidar do filho.

Dessa forma, os contatos que realiza com a família são estimulados para fornecer orientações destinadas a prepará-la sobre a melhor forma de agir para o bem-estar da criança.

ENT 4: “... não tem como separar. Não há como olhar só para a criança, só para um bebê, e não pensar que ele tem uma mãe que com certeza está influenciando na doença dele, que está influenciando em tudo. Ela é a pessoa que vai determinar seu crescimento e desenvolvimento, e há também um pai, uma avó. Cada pessoa é singular, então tudo isso vai influenciar tanto 
naquela doença como no tipo de cuidado que Ihe será oferecido. Então eu acho que a gente tem que aproveitar qualquer oportunidade que surja para orientar..."

ENT 8: "...que é gostoso você mostrar seu sentimento, se envolver com quem teve um filho. Você cuida e às vezes até se emociona (lágrimas), mesmo com algumas mães com as quais a gente cria esse vínculo, que são por vezes tão jovenzinhas. Em outros casos, em contrapartida, há dificuldade e às vezes até um préjulgamento. Pensamos no que deve passar pela cabeça da pessoa que não quer cuidar, que não quer fazer. Então acho que trabalhar é isso, não pensar só no momento da internação. A gente acaba se envolvendo mesmo e pensando um pouco no futuro dessas crianças. É o que eu sinto..."

\subsubsection{A família nem sempre corresponde ao que se espera}

A enfermeira se envolve com a criança doente e desenvolve maneiras de cuidar visando seu bem-estar, isto é, se empenha na prestação do melhor cuidado a ela.

Por isso, a enfermeira cria uma expectativa quanto ao entendimento da família em relação ao cuidado prestado à criança. No momento em que percebe a existência de alguma lacuna de interação face às necessidades diferentes dos familiares, passa a acreditar que eles não têm recursos internos para lidar com a doença e a hospitalização, identificando limites na ação da família.

ENT 2: “... embora em outras situações a gente insista, insista, trabalhe e trabalhe e ainda assim ocorre frustração por não haver resposta. A família não corresponde, não tem bagagem interior, disponibilidade e recursos internos pra conseguir responder às necessidades ou àquilo que a gente espera..." 
PROPOSIÇÃO 2: Engajar a família no cuidado para atender às necessidades da criança.

\section{SUBCATEGORIA:}

\subsubsection{Atender às demandas da criança}

A enfermeira crê que ao engajar a família no cuidado à criança, de alguma forma está atendendo às suas demandas de cuidado, já que oferece os melhores cuidados ao paciente.

Para realizar o cuidado à criança, ela busca identificar as situações de stress vivenciadas pela família, as quais estão normalmente vinculadas a situações externas ao contexto hospitalar.

Com isso, a profissional utiliza estratégias de comunicação para aproximar-se e prestar cuidado à família, e o faz sob a forma de informações sobre o estado da criança, orientando-a e envolvendo-a no cuidado.

Para tanto ela utiliza a relação face a face, bem como sua vivência pessoal e profissional anterior, que vai embasando seu cuidado à família dentro da conduta motivacional que privilegia as necessidades apresentadas pela criança.

\subsubsection{Orientar a família}

A enfermeira utiliza a orientação como forma de estabelecer vínculo com a família, demonstrando sua preocupação com o bem-estar da criança, enfatizando as rotinas hospitalares e os cuidados que podem ser realizados pelos familiares durante a internação.

A enfermeira acredita que, orientando a família nas necessidades e formas melhores de cuidado à criança sob a sua ótica profissional, contribuirá para que esse tratamento seja efetivo quando a criança receber alta.

ENT 10: “... a gente espera que alguma coisa que orientamos ou conversamos com eles durante aquele tempo fique. Procuramos orientar em relação aos cuidados que deverão ser realizados em casa, dizendo para que fiquem atentos com determinadas coisas, 
e esperamos que fique alguma coisa positiva. Ao menos é o que eu espero..."

ENT 9: "A gente orienta muito em relação à questão do cuidado do recém-nascido e também da amamentação. Ficamos o tempo todo aqui com elas..."

ENT 12: “... a gente também tem um papel muito importante na orientação das mães que estão amamentando, têm dificuldade para amamentar ou até que não querem amamentar. E a gente tem que conversar muito..."

ENT 4: "Eu acho que a gente tem que aproveitar qualquer oportunidade que a gente tenha pra orientar."

ENT14: "Minha função é sobretudo orientar alguns procedimentos, mas também localizar a mãe e falar das rotinas para que ela tente ficar mais calma. Tento criar um vínculo, o que é difícil, porque a criança fica pouco tempo aqui e eu estou sempre correndo."

ENT 15: "Dentro do possível, estando a unidade corrida ou não, buscamos dar informações quando elas são pedidas. Tem mãe que pede para ver o filho internado, e que é menor, mesmo quando o acesso é proibido pelas normas da instituição.Mas dependendo do tempo que a criança está internada vemos se dá para fazer uma liberação. Então assim para poder, que é o bem estar para própria criança que está aqui, de repente ver um irmão para visitar".

\subsubsection{Envolver a família na situação}

Outro recurso que a enfermeira utiliza para engajar a família para 0 atendimento às necessidades da criança é envolver todos os familiares na situação de saúde/doença da criança, por acreditar que dessa forma contribuirá para atender às necessidades do paciente após o período de hospitalização.

Ela também tem a crença de que envolvendo a família na situação da criança possibilitará a resolução de possíveis conflitos entre seus membros.

ENT 9: “... às vezes, se preciso, convoco a família, porque a gente tem mães adolescentes. Convocamos os pais e expomos 0 problema, dizemos o que esta acontecendo, para ver se a família também se envolve um pouco mais..." 
PROPOSIÇÃO 3: A preocupação em proteger a criança e a fragilidade da enfermeira permeiam o cuidado à família.

\section{SUBCATEGORIA:}

\subsubsection{Garantir o cuidado futuro da criança}

A motivação que permite à enfermeira cuidar da família vem dos sentimentos que ela acumula ao longo da sua experiência a fim de garantir que o futuro da criança esteja assegurado.

Assim a enfermeira se utiliza dos sentimentos que tem a respeito de família para instituir uma aproximação com a mesma visando o bem-estar futuro da criança. A enfermeira motiva-se no cuidado à família através da crença de que detém a responsabilidade sobre a melhor forma de cuidar da criança e deve envolver a família como coadjuvante nesse processo.

Apesar de estabelecer vínculos bastante consistentes com a família e com a criança a enfermeira não tem clareza do limite desses vínculos. Por isso, sua experiência pregressa com famílias e consigo mesma vai fazendo com que ela busque, por meio dos seus sentimentos, assistir de forma mais adequada a criança hospitalizada.

Esses sentimentos geram muitas expectativas em torno da melhor maneira de como a família deve assistir à criança.

A enfermeira, sentindo-se preocupada com o bem-estar da criança, motiva-se para compreender a situação da família face à hospitalização. Nesse sentido, ela busca apreender da família o que se relaciona ao seu entendimento da situação da criança. Busca então prover as necessidades advindas dessa compreensão.

ENT 2: “... a gente está sempre preocupada com o que ela (a família) está compreendendo, o que está acontecendo, se está participando, qual é o entendimento, quais são as necessidades dessa família nesse momento, se está sendo suprida, se a gente (enfermeira) pode auxiliar de alguma maneira nessa compreensão..."

ENT 3: “... Assim na naquele momento que pra ela é difícil então o sentimento é mais de uma preocupação pra amenizar a dor que ela ta sentindo..." 
ENT 8: "... eu acho que não basta apenas trabalhar como você vai cuidar do seu bebê. É preciso também dar banho,banho de sol e alimentar. A gente tem uma preocupação de como vai ser 0 futuro dessa criança, como ela vai estar inserida na sociedade..."

A enfermeira é motivada ao cuidado à família por meio da responsabilidade que atribui a si própria pelo bem-estar da criança dentro e fora do ambiente hospitalar.

Por isso, ela dirige suas ações para promover o melhor cuidado à criança, inserindo a família para certificar-se de que ela está apta para prover cuidados apropriados à criança, visto que esse sentimento permeia toda a relação que a enfermeira estabelece com 0 paciente e seus familiares.

ENT 8 : “... eu me sinto um pouco responsável. Não pensando só no momento da internação, mas no cuidado que deverá ser prestado a essa criança no domicilio..."

\subsubsection{Perceber-se vulnerável}

A enfermeira motivada pela responsabilidade busca resolver as questões da família para assegurar o conforto da criança.

Quando a enfermeira percebe que o contexto dos problemas está fora do âmbito hospitalar ela se sente vulnerável, pois nota que não terá condições de efetivar as soluções planejadas para o cuidado da criança.

A profissional se sente impotente toda vez que verifica que as situações de estresse da família estão fora do alcance hospitalar e, por causa disso, além de sua alçada.

ENT 10: "... a gente faz o que pode, mas surge uma sensação de impotência em determinadas situações, porque você percebe que não pode ajudar a resolver alguns problemas, certas situações mais difíceis. Em certos momentos a gente se sente um pouco impotente, tenta auxiliar na medida do possível aqui dentro..."

ENT 12: "... às vezes é um pouco difícil, pois a gente se sente um pouco impotente. Em muitos casos queremos ajudar mas está fora do nosso alcance..." 
Uma vez que as necessidades apontadas pela enfermeira nem sempre são as referidas pela família, ela se sente frustrada por não atingir os objetivos propostos pela mesma.

ENT 2: "... em outras situações a gente insiste, insiste, trabalha, trabalha e fica frustrada, porque não tem a resposta. A família não corresponde, não tem essa bagagem interior, não tem essa disponibilidade, não tem recursos internos pra conseguir corresponder à essa necessidade. Então a gente passa por algumas situações de muita frustração, pois mais que tenhamos atuado e feito tudo o que poderia ter sido feito. Infelizmente não é possível conseguir tudo..."

ENT 8: "... a gente fica meio frustrada (quando não consegue atingir o objetivo que é a família levar bebê para casa), porque a gente já teve casos de adoção aqui já ouve casos de adoção. A gente trabalha e acaba criando um vínculo. Não só meu como enfermeira responsável, mas toda a equipe, e acho que 0 importante nisso é que a gente se emociona, se apega. Vemos aquele envolvimento e, quando acontece abandono por parte das famílias, as meninas se juntam para comprar roupa para ela, mesmo sabendo que daqui irá para uma instituição. Sai com o enxovalzinho e com brinquedo, e quando o juizado vem todo mundo chora. Acho que isso nós conseguimos manter. Não é aquela coisa fria, aceitar que vá embora seja com quem for. A gente não consegue resolver tudo mesmo e, como sabemos dos problemas sociais acabamos pensando que talvez indo para uma adoção a criança vai estar melhor. Você acaba vendo a realidade da família daquela mãe, que realmente não tem condições e não desejou a gravidez. talvez para a criança acabe sendo a melhor opção naquele momento. Então a gente torce para que ela tenha uma família que Ihe dê tudo o que ela vai precisar."

Da mesma forma a enfermeira sente um desgaste por ter se esforçado na tentativa de resolver as necessidades da família que quer 0 conforto da criança. Isso demanda tempo e envolvimento emocional com a situação dos familiares, o que muitas vezes ultrapassa seu próprio limite.

Contudo, as necessidades apontadas pela enfermeira nem sempre correspondem às necessidades que a família de fato tem naquele momento da hospitalização, o que pode gerar absorção e entendimento mínimos das orientações que a enfermeira fornece aos familiares.

Assim sendo, o desgaste acontece como resultado da evidência de não satisfação, decorrente da não obtenção dos resultados esperados.

ENT 2 "... acho que é da equipe inteira, mas a gente percebe que há uma demanda emocional grande. É preciso tentar ajudar essa 
família, tentar interpretar essas situações junto com ela e ir elaborando, mostrando, tentando mostrar algumas possibilidades. Ajudá-la a elaborar uma maneira de tentar resolver, melhorar algumas situações, e às vezes a gente se depara com um sentimento de impotência, de frustração muito grande. Mas temos que tentar superá-lo, não é? É meio difícil, porque a demanda grande, é o dia a dia da gente lidar com essas questões todas. Há todo um investimento para melhorar essa situação, para a criança ter alta e sair numa condição melhor. Você tenta preparar essa família para voltar pra casa e conseguir suprir pelo menos as necessidades dessa criança, visando à recuperação e evitando uma reinternação. Na maioria das vezes, entretanto, a gente sabe que não vai conseguir atingir totalmente esse objetivo ,e isso gera uma frustração muito grande. Atualmente acho que estou lidando melhor com isso, mas precisei de muito tempo de terapia para não ter um custo emocional tão grande. Muitas vezes eu saí daqui muito mal, sem energia. Me desgastava muito e não trabalhava essas questões..."

\subsubsection{Perceber-se despreparada}

A enfermeira percebe-se despreparada para lidar com a família quando não encontra tempo para estar com ela ou quando acredita que a necessidade por ela trazida não é parte da sua função.

Dessa forma, ela se percebe despreparada quando não consegue resolver as questões que identifica na família e se questiona sobre maneiras de suprir suas próprias lacunas de conhecimento para atender aos familiares em suas demandas de cuidado.

ENT 6: “... há outras questões como, por exemplo, a família vem várias vezes para o Pronto Socorro. O que está acontecendo com essa família, porque ela vem várias vezes parar no Pronto Socorro? E, por exemplo, no caso daquela família quem cuida da criança é a avó, e não a mãe. Esse outro aspecto eu não consigo abordar, não sei se talvez pelo meu tempo de trabalho. Quando digo tempo de trabalho, me refiro ao tempo que tenho para resolver a questão. Isso eu não consigo abordar, não sei como abordar. Não sei se é falha do meu trabalho, se eu poderia estudar mais, mas com essa questão eu não ainda não consigo lidar, mesmo porque a família vai para a alta, ou para a pediatria, e no dia seguinte não está mais lá..."

ENT 12: “... a gente quer tranquilizar os familiares e muitas vezes também não está preparado para isso, não tem um a formação para isso..."

Diante de reflexões como essa, a profissional se sente insatisfeita consigo mesma. 
ENT 14: "Ás vezes eu sinto que poderia fazer mais."

PROPOSIÇÃo 4: Integrar a família aos cuidados visando o futuro da criança.

\section{SUBCATEGORIA:}

\subsubsection{Integrar a família no cuidado}

A enfermeira motiva-se em assegurar o bem-estar futuro da criança e pretende, com ações e intenções, desenvolver meios para agregar a família no cuidado ao paciente, e com isso melhorar a qualidade de vida da criança.

Por meio da coleta de informações sobre a família e a saúde da criança, desenvolve o vínculo que foi inicialmente estabelecido com ambas ao longo do atendimento hospitalar.

\subsubsection{Ter a criança cuidada}

Na medida em que a enfermeira se motiva a integrar a família no cuidado à criança, ela assegura que a assistência que acredita ser a melhor, será realizada no futuro pelos familiares.

ENT 14: "Primeiro é importante mostrar que a gente está ali para cuidar do filho, ver a necessidade da criança. A mãe diz que seu filho está sentindo dor, então eu vou lá e vejo se é dor mesmo e se há medicação. A gente vai esclarecer para aquela mãe o que está sendo feito com a criança, o que ela está apresentando e se está cansada. A mãe, por sua vez, já quer saber quando vai embora."

ENT 10: "Ah, eu penso que a partir do momento em que você tem uma criança hospitalizada, há todo um contexto ali, e muitas vezes a gente se depara com situações tranquilas, mas em outras a gente se depara também com circunstâncias um pouco mais complexas. E por mais tranquila que seja, a hospitalização vem sempre acompanhada de insegurança e receio. Muitas vezes também de angústia, então a gente sabe que, além de estar cuidando de uma criança, tem que dar também atenção aos familiares."

ENT 10: "Muitas mães trazem as crianças para que as vejamos. Algumas as trazem até muitas vezes, o que nos deixa felizes por saber que ela está bem, está bem cuidada e a mãe também. Você percebe que ela tem satisfação em vir mostrar a criança, como cresceu e como que está bonito. Então é gostoso,porque parece 
que tudo aquilo que vivenciou lá atrás passou. Nem parece que foi tudo aquilo ocorreu. É muito gostoso."

ENT 8: "Aqui a gente observa não só o contato em relação aos cuidados com o bebê, mas também a parte mais afetiva, o vínculo que essa família tem com o seu filho. Quando presenciamos um caso de abandono ou rejeição, procuramos tomar algumas medidas necessárias, como encaminhá-lo para outros profissionais. Buscamos integrar a família, dando o apoio devido dentro das condições da instituição."

\subsubsection{Diminuir o número de internações}

A motivação da enfermeira no cuidado à família é fazer com que, no cuidado à criança, o número de internações diminua, o que a faz desenvolver maneiras de tornar suas ações efetivas durante $o$ atendimento.

ENT 4: “... quando a gente consegue, além de cuidar só da doença da criança, olhar também para a família, acho que a chance dessa criança precisar de uma posterior reinternação diminui."

ENT 2: "O que eu espero é que esse cuidado contribua para a recuperação da criança e da família, para a maneira como a família vai cuidar dessa criança ou entender esse cuidado, essa necessidade. E que no futuro ela possa realizar isso (o cuidado) visando atender melhor tais necessidades, evitando futuras internações e propiciando uma recuperação mais rápida. Tudo isso provê à criança uma qualidade de vida melhor."

ENT 4: “... o que eu espero na verdade é qualidade de vida, e que a criança que estou atendendo reinterne o mínimo de vezes possível. Por isso aproveito a oportunidade para aumentar o conhecimento daquela mãe..."

\subsubsection{Acalmar e apoiar a família}

Com a intenção de tranquilizar a família da criança em situação de doença, a enfermeira visa integrá-la nos cuidados, fornecendo informações sobre o estado de saúde do paciente e os trabalhos de enfermagem. Esse procedimento permite que a família sinta-se segura quanto à assistência prestada ao filho, e essa segurança repercute, por sua vez, na enfermeira, a qual se tranquiliza em relação ao processo de hospitalização da criança. 
informação que você dá. Você vê a mãe falando no telefone com os familiares. Assim você acalma a família..."

ENT 3: "... então a minha intenção é aliviar um pouco o sofrimento, deixar a pessoa um pouco mais tranquila, fazendo com que saiba que, caso vá embora, a criança estará sendo bem cuidada..."

ENT 3: "Agora tem a questão da humanização, não é? $A$ introdução dos pais nos cuidados, sua participação. Então eu espero poder aliviar o sofrimento e a ansiedade deles. No contexto do sofrimento, eles devem se sentir melhor me conhecendo, sabendo quem eu sou e que estou tentando melhorar as condições do filho ."

A enfermeira identifica que, ao promover segurança nos cuidados prestados à criança, a família fica mais confiante durante o atendimento e confortada em seus temores acerca do estado de saúde da criança.

ENT 12: “... o nosso intuito é conseguir transmitir conforto e segurança, e fazer com que essa fase da vida da família da criança hospitalizada aconteça da melhor forma possível. Nunca vai ser uma experiência boa, mas que isso aconteça da melhor forma possivel, sem grandes traumas, sem grandes problemas."

ENT 15: "É importante tentar dar um pouco de conforto para a mãe na medida do possível, já que não há um lugar muito adequado para ela descansar."

Dessa forma, a enfermeira se esforça para dar segurança à família, demonstrando que a criança está tendo um cuidado efetivo. Ao mesmo tempo, ela mesma vai criando vínculos emocionais, modificando o seu o entendimento a respeito do cuidado à criança.

ENT 16: “... pela abordagem que a gente tem no início a visão da família muda e ela se sente amparada..."

ENT 15: "A partir do momento em que você cuida um pouco mais dela [família], dá um pouco mais de atenção, ela também se sente segura, sabe que você [enfermeira] vai fazer o melhor. Se porventura ela precisar ir até a casa dela poderá ir tranqüila, pois sabe que tem alguém olhando a criança. Os familiares ficam mais tranquilos, mais confiantes no serviço, e isso é importante."

ENT 9: "... mesmo depois da alta a gente se envolve bastante com as mães. Elas acabam criando esse vinculo emocional com a gente também. Não é só uma questão de técnica. O fator emocional influencia, não há como não se envolver com as histórias, com a história de vida que a família está passando. Então a gente tenta ajudar não só na parte biológica do bebê, mas também na questão da vida real, social. Muitas famílias aqui têm 
problemas sociais, muita mães adolescentes. Por isso a gente se envolve, acaba se envolvendo na questão emocional, tenta ajudar em todos esses aspectos, porque querendo ou não acabamos sendo uma referência para a mãe, um modelo de como deve ser o cuidado da criança..."

ENT 12: “... tentar passar segurança para a mãe por meio do que a gente fala que está sendo feito. Fazemos com que tenha conforto, esteja em contato e saiba que estamos sempre por perto..."

ENT 12: "Normalmente o perfil mais comum que temos aqui é o de famílias em situação de crise. Os familiares estão estressados, preocupados e fragilizados, portanto precisamos ter muita sensibilidade e muita calma, para transmitir confiança e conseguir lidar com eles."

ENT 13: "Eu acho que elas se sentem confiantes e até mais tranquilos quando sabem que quem está ali cuidando do filho é uma pessoa que trabalha com carinho, que está demonstrando preocupação e não apenas cumprindo uma mera tarefa. Creio que isso os deixa muito confiantes e, aqui na UTI pediátrica, desde que comecei a trabalhar, percebi muito claramente - e isso foi uma coisa que me envolveu muito fortemente - que todas as pessoas gostam muito do que fazem. Não tem uma só pessoa que esteja aqui trabalhando e demonstre má vontade. Não tem mesmo. As pessoas gostam muito do que fazem, gostam muito de estar aqui apesar de uma ou outra coisa séria que acontece. Mas é só pela característica pessoal, porque o prazer de estar fazendo também existe. $E$ isso é muito bacana. É muito bom trabalhar num lugar assim, apesar de tanto sofrimento que a gente às vezes enfrenta. É uma coisa de união, de energia muito forte, muito positiva. $E$ isso é bom."

\title{
4.2.4.6 Sentir-se bem e reconhecida pela família
}

\author{
A enfermeira avalia a qualidade da sua assistência no sentido de \\ melhorá-la. Quando se sente satisfeita com o resultado é porque a família \\ aprovou os serviços prestados.
}

ENT 16: "... eu me sinto satisfeita porque sei que estou fazendo o bem tanto para a família como para a criança. Não tenho problema algum. Mesmo que a criança esteja sofrendo, eu não sofro junto. Tento fazer o melhor para cuidar daquela criança e para que ela saia bem, ainda que o diagnóstico seja crônico e saibamos que não há nada a ser feito. Mesmo nesses casos tentamos cuidar com amor e carinho e dar o melhor de nós..."

ENT 16: “... Eu espero que ela se sinta bem, pois além de estar fora de casa encontra-se em um ambiente totalmente diferente, vivenciando uma situação que é estressante e deixando a vida dela lá fora para entrar numa rotina aqui dentro. Às vezes tem um emprego e precisa faltar para ficar com a criança, ou tem seis 
filhos em casa e ninguém com quem possa deixá-los. Tem que cuidar do filho aqui e ainda lembrar dos outros seis. Assim eu tento fazer da melhor maneira possível, para que a pessoa se sinta bem pelo menos enquanto estiver nesse momento. Digo que, caso ela queira ir embora, eu cuido do filho até que possa voltar..."

ENT 15: "Eu espero que a família possa sair daqui satisfeita e com a criança restabelecida. Em caso de óbito é claro que isso não ocorre, mas esperamos que ela tenha ciência de que não só eu, como todos da equipe, fizemos tudo o que era possível. Não queremos que a pessoa saia reclamando dos serviços de alguma enfermeira ou sentindo que precisava de alguma coisa e não foi ajudada.Há momentos mais corridos nos quais o auxílio não pode ser imediato, mas hora ou outra voltamos e damos um retorno."

ENT 11: "O bem-estar é importante para todos. Você percebe que ajudando, fazendo a sua parte, a consciência já fica mais tranquila. Constata que fez o que pôde, deu o melhor de si e na maioria das vezes acertou."

Ser reconhecida pela família permite à enfermeira reavaliar e perceber a diferença que a assistência fez, mesmo quando na sua autoavaliação ela não sente que procedeu de forma adequada.

ENT 16: “... se sentem (as famílias) bem quando elogiam o que a gente está fazendo..."

ENT 11: "É gratificante, é muito gratificante. Como no caso dessa mãe aqui no berçário. Ela diz " $F$, eu estou indo embora hoje graças a você também ter me ajudado e incentivado a ordenhar." Tem uma outra mãe lá na pediatria também que fala "Ah, eu gosto de conversar com você, porque você me explica de um jeito que só você consegue. Eu consigo entender só com você. Às vezes os médicos vêm, falam, falam, falam, mas eu venho perguntar para você de novo porque eu consigo entender do jeito que você me explica. E aí você fica mais, é mais gratificante ainda o trabalho na pediatria. Eu acho o trabalho na pediatria muito gratificante, gosto muito, e ai quando você tem esse retorno, esse feedback com as mães, se torna ainda melhor. Eu gosto muito."

ENT 9: "Eu espero que isso faça alguma diferença para eles posteriormente, porque as mães que ficam aqui internadas parecem sair mais seguras com o bebê para casa. $O$ que eu espero é que em casa ela consiga colocar em prática tudo o que viu e aprendeu e todas as coisas que a gente fala, repete milhões de vezes. Espero que nossa contribuição ajude essa família a cuidar da criança em casa de uma maneira mais tranquila. Às vezes se trata de um bebê prematuro que exige muitos cuidados, é uma situação mais delicada. Espero sempre que ela tenha conseguido entender essas questões relacionadas ao bebê, e acho que faz diferença sim, pois elas vão para casa e depois nos contam. Ao menos algumas delas. Há pouco tempo tivemos uma mãe aqui que ficou o tempo todo internada com uma criança prematura. Era uma mãe adolescente, mas superenvolvida. Ficou muito tempo aqui e teve alta na semana passada. Chorou muito, 
demais, abraçou a gente, falou que era bom ir para casa mas que sentiria a nossa falta. A gente também se envolve. Ela chorou bastante, entrou na outra sala e abraçou todo mundo. A gente tem um retorno bem positivo dessas famílias, mesmo quando vão para casa. Depois trazem os bebês maiores para a gente os veja. É gratificante, porque a gente acaba acompanhando um pouco a história de vida dessas crianças, sobretudo dos que têm algum problema. Os demais vão para o posto e a gente não os vê crescer, mas os prematuros, os que têm problemas e os neurológicos ficam bastante tempo aqui. Depois vão para casa, mas muitos acabam reinternando. Reinternam na pediatria, e elas vêm e nos avisam, pedem para que vamos verificá-los. Nós então vamos, visitamos até que haja alta. Essas mães de crianças que ficam mais tempo acabam voltando e a gente está sempre reencontrando um ou outro."

Ter a consciência tranquila quanto ao cuidado desempenhado traduz a conquista do objetivo da enfermeira de ter a criança com um quadro de saúde melhorado.

ENT 2: "... eu acho que de modo geral a gente consegue atingir esse objetivo (recuperação mais rápida e uma qualidade de vida melhor), o que dá uma satisfação muito grande..."

ENT 14: "... é bem gratificante. Eu trabalho gosto bastante de trabalhar com criança e saber que estou ali no momento mais difícil, sobretudo para a mãe de uma criança internada, momento crucial. É bom estar perto para poder ajudar a cuidar da criança e acalmar a mãe. Às vezes você a tira da sala se percebe que ela não vai aguentar. Dá um copo de água e faz o que puder. Me sinto muito bem fazendo isso..."

ENT 8: “... a gente sente gratificação quando essas crianças retornam, já que a maioria, principalmente os prematuros, são acompanhados até os dois anos de idade. Quando eles retornam percebemos tudo o que conseguimos passar para a família. Há mães que, toda vez que vêm, trazem os filhos para mostrar para a equipe. Essa conduta denota reconhecimento. É uma forma de agradecer o que a gente fez por eles..."

ENT 12: "... algumas vezes a gente se sente muito gratificado com os resultados obtidos. Tem muitas vezes que a gente cria vínculos muito significativos com as mães e com as famílias, além de nos sentirmos muito gratificados..."

ENT 14: "Espero estar com a minha consciência tranquila em relação ao que eu fiz e ao que poderia ter feito. Dei a atenção que os familiares mereciam, ajudei não só a olhar a família, mas a criança a estar satisfeita com o meu trabalho, a estar feliz." 


\subsection{TIPO VIVIDO}

Para que pudesse ser construído o tipo vivido da enfermeira no cuidado à família da criança hospitalizada foi necessário resgatar as motivações e as convergências de seu significado.

O sistema de relevâncias e tipificações socialmente aprovado é o campo comum dentro do qual as tipificações e estruturas de relevâncias privadas dos membros individuais do grupo se originam. Isto é assim porque a situação particular do indivíduo, conforme definida por ele, é sempre uma situação dentro do grupo, seus interesses privados são interesses com referência aqueles do grupo, seus problemas particulares estão necessariamente no mesmo contexto dos problemas do grupo ${ }^{45}$.

Assim, o tipo vivido da enfermeira no cuidado à família da criança hospitalizada é apresentado em duas condutas motivacionais. Na primeira o cuidado da enfermeira é caracterizado por Incluir a família, pois para ela pensar na família é fundamental. Com isso, sente necessidade de atender às demandas da família durante a hospitalização e de aprimorar seus conhecimentos quanto á abordagem da família. $\mathrm{Na}$ segunda conduta, o cuidado da enfermeira se caracteriza por Engajar a família na assistência prestada à criança. Para a enfermeira a presença da família é importante, e a necessidade de integrar a família no cuidado e atender às demandas da criança são modos de garantir o cuidado futuro da criança.

Os pressupostos da Fenomenologia Social permitiram compreender os motivos por que e os motivos para da enfermeira no cuidado à família da criança hospitalizada.

Os homens têm faculdades próprias de conhecer, pelo espírito, a distinção das idéias e das coisas para as suas ações e preocupam-se com elas. Essas razões estão enraizadas em experiências passadas, na personalidade que um homem desenvolveu durante sua vida, denominado motivos por que ${ }^{46}$. O motivo para é, portanto, um contexto de significado que é construído ou se constrói sobre o contexto de experiências disponíveis no momento da projeção (essa categoria é essencialmente subjetiva) $)^{50}$. 
A ação social vinculada a Incluir a família como forma de cuidado realizado pela enfermeira está contida nos benefícios que a enfermeira identifica para si mesma, para a família e conseqüentemente para a criança e na percepção de que este modo de cuidar vai sendo incorporado pela equipe de enfermagem na vida cotidiana pediátrica.

Em constante interação social com a família inserida no seu mundo vida, é a relação face a face da enfermeira com a família que favorece o relacionamento e a vinculação de ambos bem como o bem estar da família. Ao estender seu foco de cuidado para toda a família e não apenas para a criança doente, revelam-se aspectos da intersubjetividade experimentada pela enfermeira.

O mundo vida é entendido como um mundo natural, que impõe limite às nossas atitudes, na qual atuamos e operamos como atores e cenário de uma realidade que modificamos mediante nossos atos, e que por outro lado transforma nossas ações ${ }^{45}$.

No mundo vida da enfermeira já está presente a filosofia da permanência dos pais acompanhando a criança hospitalizada durante as 24 horas do dia. É na relação face a face com a família, que a enfermeira se sente segura e confiante de si mesma para desenvolver um vinculo positivo no cuidado à família.

Quando estou face a face com meu semelhante, percebo seu corpo, suas expressões e me comunico com ele através de todos os seus gestos, sendo possível compreendê-lo, captando sua essência como uma pessoa determinada presente aqui e agora ${ }^{55}$.

A enfermeira alia a sua própria bagagem de conhecimentos e situação biográfica para desenvolver o cuidado à família, de modo a reduzir o stress e o sofrimento da família.

A intersubjetividade no cuidado à família, aliada a sua bagagem de conhecimentos em colocar-se no lugar da família, propiciam à enfermeira uma aproximação com a família e assim vai construindo vínculos entre todos.

Essa atitude em cuidar da família da criança hospitalizada gera uma motivação nas ações da enfermeira através da relação face a face e da, 
intersubjetivade ampliando a sensibilidade às demandas da família decorrentes da doença da criança.

A enfermeira, em seu mundo vida, utiliza sua bagagem de conhecimentos e sua situação biográfica em busca uma melhor forma de atender a família, proporcionando condições para que a família consiga restabelecer-se do advento da doença de um membro da família.

A enfermeira utiliza a relação face a face, a fim de entender a dinâmica familiar e a pensar maneiras que possam auxiliá-las a transpor essa fase, assim como formar vínculos entre todos.

E a condição para que eu tenha uma experiência direta de meu próximo é a de que ele divida comigo um setor de tempo e espaço existindo uma simultaneidade de dois fluxos de consciência, sendo o corpo do meu próximo um campo de expressão de acordo com a forma que a forma que a vida do outro se manifesta para mim $^{49}$.

A enfermeira pretende ao Incluir a família, que o cuidado à família seja incorporado por toda a equipe de enfermagem e equipe multiprofissional no seu mundo da vida cotidiana.

\begin{abstract}
A idealização da reciprocidade de perspectiva pressupõe que eu possa trocar de lugar com o meu semelhante e vir a conhecer seu ponto de vista, assim como ele pode conhecer o meu, esse fenômeno é denominado por Schtuz como conhecimento em comun $^{49}$.
\end{abstract}

A ação social vinculada a Engajar a família como forma de cuidado realizada pela enfermeira está no atendimento às necessidades da criança minimizando assim o sofrimento da criança em função da experiência da sua doença.

A enfermeira utiliza a relação face a face e sua bagagem de conhecimentos para embasar o cuidado à família dentro do contexto e das necessidades apresentadas pela criança. A família torna-se importante no contexto de cuidar da criança na medida em que a enfermeira, em sua vida cotidiana avalia-a como parte no processo de melhora da criança e como recurso que garantirá a manutenção da condição de saúde após a hospitalização. 
A bagagem de conhecimentos juntamente com a intersubjetividade fazem com que a enfermeira sinta-se responsável pela criança e pelo que acontece no seu em torno a partir do advento da doença onde a família faz parte do universo vivido pela criança.

É na relação face-a-face que a enfermeira capacita e orienta a família para o cuidado a criança, coerente com sua situação biográfica e sua intersubjetividade atribuindo a si própria a responsabilidade pela criança.

$\mathrm{Na}$ relação face a face que se estabelece com a família a enfermeira percebe que na maioria das vezes os problemas que a família vivência situam-se fora do ambiente familiar, portanto fora da sua condição de solução. Assim, pela intersubjetividade ela se sente impotente diante dessa constatação e frustrada por não poder intervir diante desse fato, gerando desgaste emocional na enfermeira.

No mundo da vida cotidiana da enfermeira por ter como foco o cuidado da criança, em alguns momentos percebe-se sem tempo para estar com a família, Acreditando ser necessária uma aproximação conhece a necessidade da família e o seu não atendimento.

A enfermeira utiliza a orientação, na relação face-a-face, como forma de estabelecer vínculo com a família, demonstrando sua preocupação com o bem estar da criança, onde enfatiza as rotinas hospitalares e os cuidados que podem ser realizados pela família durante a internação e envolvendo toda a família na situação de saúde da criança por acreditar que dessa forma estará contribuindo para satisfazer as necessidades da criança após o período de hospitalização.

\subsection{DISCUSSÃO DO TIPO VIVIDO}

Os resultados deste estudo revelaram duas condutas motivacionais relacionados ao fenômeno do cuidado da enfermeira à família com crianças hospitalizadas: um cuidado que visa INCLUIR A FAMÍLIA no cuidado e o outro que visa ENGAJAR A FAMÍLIA no cuidado à criança. 
As categorias que emergiram do estudo trazem elementos importantes para a compreensão da experiência de cuidar da família no contexto de doença e hospitalização da criança.

Á partir da compreensão da experiência da enfermeira, foi possível apreender as ações que caracterizam o cuidado à família e as experiências de significados subjetivos que atuam na conduta da enfermeira em relação à família, posto que presentes em sua vida interior, afetam o mundo exterior.

As categorias identificadas, não indicam características das enfermeiras, mas projetos preconcebidos de norteiam as suas ações cotidianas em relação à família. Trata-se de comportamentos motivados, seja por uma finalidade, quando se refere ao futuro (motivos para) ou por um contexto de experiências passadas ou situação pessoal (motivos porque).

A distinção da conduta motivacional é um elemento importante nos resultados do estudo, pois revelam motivos, cujos significados subjetivos e objetivos, podem determinar o cuidado à família, como algo intencionalmente projetado pela enfermeira, o que transforma o cuidado em ação consciente.

Estes resultados são coerentes com evidências de estudos sobre a interação de enfermeiros e famílias, no que diz respeito à ação intencional. As interações inter-pessoais significativas desenvolvidas ao longo da experiência da família evidenciam um jeito de ser e estar com a família, cujas intervenções efetivas refletem as atitudes $e$ as competências relacionadas dos profissionais de saúde ${ }^{56}$.

Os resultados do estudo relacionam-se diretamente ao tema da abordagem centrada na família. O termo "cuidado centrado na família" é amplamente usado em pediatria, embora como um modelo de cuidado pareça ambíguo ${ }^{57}$ a literatura traz incontáveis relatos de experiência de implementação do modelo ou abordagem, que se relacionam aos resultados obtidos no que se refere ao cuidado que visa INCLUIR A FAMíLIA.

Na categoria INCLUIR A FAMÍLIA a enfermeira considera a família como unidade de cuidado em que a criança faz parte, aspecto essencial para o seu atendimento, que se dirige a uma parceria que beneficia mutuamente o enfermeiro e a família. 
Estudo $^{58}$ que relata a experiência de transição para a abordagem centrada na família também destaca a visão do enfermeiro acerca da família como uma extensão do paciente e portanto, parte do seu cotidiano prático. As crenças do enfermeiro em relação à família como sujeito de cuidado são destacadas em estudo que aborda a mobilização do enfermeiro para a família ${ }^{22}$.

Outro aspecto que emergiu do estudo foi que INCLUIR A FAMíLIA reflete uma motivação da enfermeira de que o seu comportamento nas ações de cuidado à família seja incorporado igualmente pelo restante da equipe e ela o faz de forma intencional a fim de ser integrado pela equipe.

A literatura ${ }^{59}$ indica que muitas lições valiosas foram aprendidas durante o processo de mudança para uma abordagem centrada na família, que além de auxiliar a equipe a proporcionar mais amor, atenção e esperança para os pacientes e suas famílias, aumentou o orgulho dos funcionários da unidade e na prática clínica, o que gerou uma mudança no ambiente físico da unidade e na cultura dos funcionários que integram os conceitos do cuidado centrado na família ${ }^{60,61}$.

Outro resultado relevante é que a enfermeira para INCLUIR A FAMÍLIA no cuidado é motivada a melhorar a qualidade da assistência e quando ela retoma com sua equipe as ações efetuadas por ela, certifica-se da satisfação da equipe com o cuidado que prestou e a família se sentiu cuidada e atendida em suas demandas de cuidado.

Estes resultados são confirmados pela literatura, quando afirma que o cuidado centrado na família não beneficia apenas a criança e sua família, mas a equipe tem um funcionamento mais eficiente com a participação ativa da família, com diminuição do tempo gasto em monitorar as visitas e com isso ter maior contato com a paciente, gerando maior satisfação durante o trabalho ${ }^{62}$. Além disso, há o impacto positivo no nível de stress da equipe e da família e a melhora da receptividade da equipe ${ }^{63}$.

Com o desejo de aprimorar a abordagem à família para apropriá-la do cuidado do seu filho, a enfermeira busca formas de estar em constante movimento em prol do aculturamento dessa forma de cuidado, mesmo 
sabendo que esse processo se dá em longo prazo, pois mobiliza mudanças de crenças e valores de todos os componentes da equipe.

Apesar da mobilização e mudanças que fazem parte do processo de aculturamento, o fato de já exercer atividade no ambiente pediátrico, confere a equipe condições de prestar cuidado efetivo a esta população especifica.

Este fato somado à formação e a educação sobre os modelos que favoreçam uma abordagem centrada na família seja uma razão pela qual a unidade atinja o objetivo de prestar um cuidado amigável, com diminuição do estresse da criança e da família durante a hospitalização ${ }^{19}$.

Na categoria ENGAJAR A FAMILIA no cuidado a enfermeira tem a criança como unidade de cuidado, sendo a família importante para a manutenção e restabelecimento da criança. Um aspecto da motivação da enfermeira para ENGAJAR A FAMILIA no cuidado reside na crença de que é sua a responsabilidade do bem estar da criança, bem como a garantia de seu cuidado futuro e diminuição no número de re internações.

Esta categoria apresenta aspectos que se aproximam dos desafios e barreiras em relação à incorporar o cuidado centrado na família. Embora o enfermeiro reconheça a importância de assumir a responsabilidade e cuidar da família, ele ainda vê limitações em sua participação, acredita e espera que a família atue mais no sentido de dar conforto e os cuidados que a criança necessita, cabendo à ela, enfermeira, o papel de orientar e ensinar a família em relação ao cuidado da criança ${ }^{65,66,67}$.

O conflito íntimo vivenciado por cada profissional quanto à presença da família na UTI neonatal ou Pediátrica, pois sente dificuldade de inserir a família no cotidiano da unidade ao tempo em que reconhecem a importância da família no processo de hospitalização da criança ${ }^{3}$ é também um aspecto identificado na vivência dos enfermeiros em nosso estudo.

Esta categoria destaca o intenso envolvimento do enfermeiro na recuperação da criança, coerente com estudos que também indicam que os profissionais querem fazer e dar o melhor de si para ajudar a criança a se recuperar o mais rápido possível, passar segurança e estabelecer uma relação de confiança com a criança, onde a família é inserida visando à continuidade do tratamento da criança no domicilio com o objetivo de 
diminuir as re-internações decorrentes dos cuidados prestados inadequadamente em casa ${ }^{68}$, e a família é vista como um recurso para cuidar da criança após a alta ${ }^{37}$.

Uma evidência importante desta categoria, refere-se à sensação de despreparo e fragilidade da enfermeira quando esta não consegue solucionar os problemas que identifica na família e percebe que existe uma lacuna de conhecimentos e recursos para atender às demandas de cuidado que a família necessita. e sente-se despreparada e vulnerável.

Estudos também destacam este aspecto da experiência do enfermeiro na sua relação com a abordagem centrada na família, nos quais 0 enfermeiro identifica sua próprias limitações para lidar com as situações da família com eficiência ${ }^{66,69,70}$.

No Brasil, vários estudos também vem reforçar esses achados, revelando que as enfermeiras cobram de si uma assistência mais humanizada, embora não estejam preparadas para esta relação ${ }^{71}$,que há um despreparo na forma de abordagem à criança-família no dia a dia da hospitalização ${ }^{72}$, por falta de conhecimento que dê suporte para trabalhar com as necessidades criança/família ${ }^{72,73}$.

Outro estudo também se refere ao despreparo da enfermeira que mencionam a falta de um arcabouço teórico que possa conduzi-los a assistir as famílias, fato esse que os leva a manifestarem dificuldades em aceitar e acolher as famílias com seus filhos em unidades de terapia intensiva ${ }^{64}$.

Outro resultado relevante da categoria ENGAJAR A FAMILIA no cuidado, é o que revela os sentimentos de bem estar e reconhecimento que a enfermeira tem quando a criança tem alta e quando a família reconhece sua participação no processo, ressaltando a importância que percebe da família junto à criança e do seu papel junto à família.

A literatura apresenta em relatos ${ }^{14}$ e estudos $^{16}$ relativos à abordagem centrada na família, que muitas idéias contidas nos conceitos de serviços centrados na família não são novos e muitos profissionais de saúde consideram que já os praticam porém existe também uma dicotomia entre a sua participação da família no cuidado, característico de um cuidado que visa ENGAJAR A FAMíLIA. 
CONSIDERAÇÕES FINAIS 


\section{CONSIDERAÇÕES FINAIS}

Os resultados deste estudo sustentam a evidência de que a enfermeira também tem necessidade de aprimorar o seu cuidado à família e proporcionar um contexto para que ela, assim como a família, consiga estabelecer claramente seu papel ao longo do processo interacional que se estabelece na hospitalização da criança e definir também as demandas emergentes na situação, para ambas.

O estudo evidenciou que a vivência da enfermeira no cuidado à família prestado não é única, nem tampouco uniforme, que suas motivações ainda se dão no âmbito individual, conforme a bagagem de conhecimento de cada profissional, mas que é possível caracterizar comportamentos e atitudes típicos.

Embora a realização do estudo com uma população de enfermeiras de um hospital universitário, seja uma limitação, já que não permite generalizações, os resultados trazem importantes elementos para a compreensão dos desafios para a implantação do cuidado centrado na família em nosso meio.

Mover-se de um ponto em que se assume pessoalmente a filosofia de cuidado centrado na família para outro que consiste em implementá-la de fato no âmbito institucional, pode apresentar muitos desafios. Cuidado centrado na família em pediatria representa parceria estabelecida entre o profissional e a família para um cuidado próximo e negociado, tendo a criança como centro. Como qualquer coisa que afeta a criança também causa impacto sobre a família, o cuidado destinado à criança em relação à sua situação de doença, deve ser planejado considerando toda a família. Para tanto, lidar de maneira eficiente com a família em situação de doença implica em que profissional tenha boas habilidades de comunicação e de negociação, para focalizar a família como unidade de cuidado.

Assim consideramos algumas implicações dos resultados deste estudo para a ampliação do cuidado centrado na família em instituições hospitalares: 
- O cuidado centrado na família, como modelo de assistência, deve ser parte da formação e do treinamento do enfermeiro, em todos os níveis de formação.

- Habilidades de comunicação e de negociação, avaliação da dinâmica e funcionamento familiar devem ser competências requeridas e desenvolvidas por enfermeiros no cotidiano da assistência.

- Oferecer espaços institucionais para o enfermeiro partilhar suas crenças sobre o cuidado à família e as barreiras que identifica, em si mesmo e no contexto, para a implementação da cuidado centrado na família, pode auxiliar na identificação de estratégias de suporte e capacitação.

- Uma instituição de formação e de referência como é um hospital universitário, deve inovar constantemente os processos assistenciais. Assim, a formulação de uma política clara de cuidado centrado na família pela instituição, pode determinar novos e mais eficientes protocolos de assistência, diagnósticos apropriados e estratégias de implantação da abordagem, norteando todas as ações e processos de treinamentos constantes relacionados ao tema, no contexto multiprofissional e não apenas direcionado ao enfermeiro.

- Educação e informação das famílias para o cuidado centrado na família, por meio de grupos de discussão, folhetos, entrevistas de admissão à instituição, como forma de ampliar o alcance da abordagem.

- Ampliar as pesquisas sobre o tema, em outros contextos assistenciais e também relacionados a outros grupos de pacientes, como gestantes, adultos, idosos, ente outros.

- Desenvolver estudos sobre estratégias de implementaçào do cuidado centrado na família, explorando as experiências de profissionais e da familia.

A partir dos pressupostos da fenomenólogia de Alfred Schütz foi possível desvelar o fenômeno: a enfermeira no cuidado à família da criança hospitalizada, e trazer à tona novas indagações sobre a filosofia do cuidado 
centrado à família e sua implementação no cotidiano da assitência de enfermagem e da saúde em geral.

Há três décadas já existem evidências científicas consistentes sobre a importância da família para o individuo no processo saúde/doença e a relevância do cuidado centrado na família para o processo de assistência em saúde e eficiência das intervenções com famílias em situação de doença. Já é conhecido também que os enfermeiros, mais do que qualquer profissional de saúde tem muitas oportunidades de trabalhar com famílias em muitos contextos de assistência.

A Enfermagem está se movendo definitivamente para um cuidado cada vez mais centrado na família. Alguns enfermeiros já têm consciência destas oportunidades e desenvolvem suas próprias e singulares formas de cuidar da família, como as formas típicas apresentadas neste estudo. É necessário, no entanto, que se instale um movimento que motive cada vez mais enfermeiros a cuidar da família transforme os cenários de assistência e assim mais serviços ofereçam um cuidado centrado na família. Com isso, amplia-se a chance de desenvolvimento de enfermagem da família no Brasil, o que refletirá este novo conceito na prática, evidenciado por avaliações e entrevistas consistentes de famílias e intervenções apropriadas.

É encorajador testemunhar o movimento em direção ao trabalho com famílias em hospitais realizados por enfermeiros e suas demandas por mais conhecimento e prática de avaliação e intervenção com família. Entretanto estas mudanças na prática continuarão a ser lentas até que os enfermeiros mudem seus pensamentos em relação a quem é o paciente. Esta mudança de pensamento resultará no reconhecimento do impacto da doença sobre a família, da influência da interação familiar sobre a doença e da reciprocidade entre os dois ${ }^{74}$. 
REFERÊNCIAS 


\section{REFERÊNCIAS}

1. Angelo M . Abrir-se para a família: superando desafios. Família, saúde e Desenvolvimento (UFPR). 1999. v. 1, n. 1/2, p. 7-14,

2. Jolley J, Shields L. The evolution of family centered care. Journal of Pediatric Nursing. 2009; 24 (2): 164-70.

3. Molina RCM, Varela PLR, Castilho AS, Bercini LO, Marcon SS. Presença da família nas Unidades de Terapia Intensiva Pediátrica e Neonatal: Visão da equipe multidisciplinar. Esc Anna Nery Rev Enferm. (2007). 11 (3): 437-44.

4. Johnson, BH. Family-centered care: Four decades of progress. Families, Systems, \& Health. (2000) 18, 137-156.

5. Harrison, TM. Family centered pediatric nursing care: State of the science. Journal of Pediatric Nursing. (2010). 25, 335-343.

6. Shields L, Pratt J, Davis L, Hunter J. Family-centred care for children in hospital. Cochrane Database of Systematic Reviews 2007, Issue1.

7. Davies R. Marking the 50th anniversary of the Platt Report: from exclusion, to toleration and parental participation in the care of the hospitalized child. J Child Health Care March 2010 14: 6-23, first published on January 5, 2010.

8. Neal A, Green A, Frost M, Cleveland BG, Kuhn J, Kersten, R. Family centered care within an infant-toddler unit. Pediatric nursing; November-December, (2007). Vol. 33; № 6; pgs: 481-487.

9. Kamerling SN, Lawler LC, Lynch M, Schwartz AJ. Family-centered care in the pediatric post anesthesia care unit: changing practice to promote parental visitation. Journal of Peri Anesthesia Nursing, (2008). Vol. 23, № 1 (February): pp 5-16.

10. Pruitt LM, Johnson A, Elliot JC, Polley K. Parental presence during pediatric invasive procedures. Journal of Pediatric Health Care, (2008) 22, 120-127.

11. Moore KAC, Coker K, DuBuisson AB, Swett B, Edwards WH. Implementing potentially better practices for improving family-centered care in neonatal intensive care units: successes and challenges. Pediatrics (2003); 111: e450-e460.

12. Corlett J, Twycro A. Negotiation of parental roles within familycentered care: a review of the research. Journal of Clinical Nursing (2006), 15, 1308-1316. 
13. Rouck SD, Leys M. Information needs of parents of children admitted to a neonatal intensive care unit: A review of the literature (19902008). Patient Education and Counseling 76 (2009) 159-173.

14. Lee $P$. What does partnership in care mean for children's nurses? Journal of Clinical Nursing. (2007); 16: 518-26.

15. Bell JM. Family Systems Nursing: Re-examined. Journal of Family Nursing. (2009). 15 (2): 123-129

16. Dias SMZ, da Motta MGC. Processo de cuidar a criança hospitalizada e família: percepção de enfermeiras. Rev Gaúcha Enferm. (2006). 27(4): 575-82.

17. Pauli MC, Bousso RS. Crenças que permeiam a humanização da assistência em unidade de terapia intensiva pediátrica. Revista latinoamericana de Enfermagem (2003) maio-junho; 11(3): 280-6.

18. Buarque V, Lima MC, Scott RP, Vasconcelos MGL. O significado do grupo de apoio para a família de recém-nascidos de risco e equipe de profissionais na unidade neonatal. Jornal de Pediatria. (2006). 82 (4): 295-301.

19. Hughes, M. Parents' and nurses' attitudes to family-centered care: an Irish perspective. Journal of Clinical Nursing (2007), 16, 2341-2348.

20. Kamada I, Rocha SMM. As expectativas de pais e profissionais de enfermagem em relação ao trabalho da enfermeira em UTIN. Rev Esc Enf USP. (2006). 40 (3): 404-11.

21. Guareschi APDF, Pinto, JP. O enfermeiro como cuidador na perspectiva da enfermagem pediátrica. Revista Nursing.(2007). 108(9): 234-7.

22. Wernet $M$, Angelo M. Mobilizando-se para a família: dando um novo sentido à família e ao cuidar. Rev Esc Enf USP. (2003). 37 (1): 19-25.

23. Martinez JG, Fonseca LMM, Cachê CGS. Participação das mães no cuidado ao filho prematuro em unidade Neonatal: Significados atribuídos pela equipe de saúde. Revista latino-americana de Enfermagem (2007) março-abril; 15(2).

24. Hedman P, Palmer JS. A critical pathway for successful outpatient uretheral re-implantation: a nursing perspective. Journal of Peri Anesthesia Nursing, (2009) Vol. 24, no 3 (June): pp 163-166.

25. Fulbrook P, Latour JM. Paediatric critical care nurses' attitudes and experiences of parental presence during cardiopulmonary resuscitation: A European survey. International Journal of Nursing Studies 44 (2007) 1238-1249. 
26. Wernet M, Angelo M. A enfermagem diante das mães na Unidade de Terapia Intensiva Neonatal. Rev Enferm UERJ. (2007).15(2): 229-35.

27. Sabatés AL, de Borba RIH. As informações recebidas pelos pais durante a hospitalização do filho. Rev Latino-am Enfermagem. (2005). 13(6): 968-73.

28. Poles K, Bousso RS. Compartilhando o processo de morte com a família: a experiência da enfermeira na UTI Pediátrica. Rev Latino-am Enfermagem. (2006). 14(2): 207-13.

29. Shields L, King SJ. Qualitative analysis of the care of children in hospital in four countries- part 1. Journal of pediatric Nursing, (2001). Vol.16, № 2 (April).

30. Pinto MCM, Camata DG, Oliveira AC, Dalge DP, Paes, AT. Significado do cuidar da criança e a percepção da família para a equipe de enfermagem. Einstein. (2009). 7 (1):18-23.

31. Cleveland, LM. Parenting in the neonatal intensive care unit. JOGNN. (2008). 37, 666-691.

32. Shields L, King SJ. Qualitative analysis of the care of children in hospital in four countries- part 2. Journal of pediatric Nursing, (2001). Vol. 16, № 3 (June).

33. Collet N, Rocha SMM. Criança hospitalizada: mãe e enfermagem compartilhando o cuidado. Rev Latino-am Enfermagem. (2004). 12(2): 191-7.

34. Petersen MF, Cohen J, Parsons, V. Family-centered care: do we practice what we preach? JOGNN, (2004). 33, 421-427.

35. Shields, L; Nixon, J. Hospital care of children in four countries. Journal of Advanced Nursing, (2004) 45(5), 475-486.

36. Meltzer LI, Steinmiller E, Simms S, Grossman M. Staff engagement during complex pediatric medical care: The role of patient, family, and treatment variables. Patient Education and Counseling (2009) 74. 7783.

37. Pedroso GER, Bousso RS. O significado de cuidar da família na UTI neonatal: crenças da equipe de enfermagem. Acta Scientiarum. Health Sciences. (2004). 26(1): 129-34.

38. Romino SL, Keatley VM, Secrest J. Good, Parental presence during anesthesia induction in children. AORNJ, 81 (April 2005) 780-792.

39. Hinkle JL, Fitzpatrick E, Oskrochi GR. Identifying the Perception of Needs of family Members Visiting and Nurses Working in the Intensive Care Unit. Journal of Neuroscience Nursing. (2009); 41(2): 86-91. 
40. Sarajärvi A, Haapamäki MI, Paavilainen E. Emotional and informational support for families during their child's illness. International Nursing Review. (2006); 53: 205-210.

41. Merighi MAB. Fenomenologia. In: Merighi MAB Praça NS. Abordagens teórico-metodológicas qualitativas: a vivência da mulher no período reprodutivo. Rio de Janeiro: Guanabara Koogan: 2003. pp. 31-8.

42. Polit D, Beck CT, Hungler F. Fundamentos da pesquisa em enfermagem. 5a Ed. Porto Alegre: Artes Médicas; 2004.

43. Merighi MAB, Praça NS. Abordagens teórico-metodológicas qualitativas: a vivência da mulher no período reprodutivo. Rio de Janeiro: Guanabara Koogan: 2003. Pesquisa qualitativa em enfermagem p. 1-3.

44. Merighi MAB. Fenomenologia. In: Merighi MAB, Praça NS. Abordagens teórico-metodológicas qualitativas: a vivência da mulher no período reprodutivo. Rio de Janeiro: Guanabara Koogan: 2003. p. 31-8.

45. Schütz A, Luckman T. Las estructuras Del mundo de la vida. Buenos Aires : Amorrortu ;1977.

46. Schütz A. El problema de La realidad social: escritos I. Buenos Aires: Amorrortu; 1974 a.

47. Merighi MAB. Enfermeiras obstétricas egressas da Escola de Enfermagem da Universidade de São Paulo: caracterização e trajetória profissional [ tese]. São Paulo: Escola de Enfermagem, Universidade de São Paulo; 2000.

48. Wagner HR, organizador. Fenomenologia e relações sociais: textos escolhidos de Alfred Schütz. Rio de Janeiro: Zahar; 1979.

49. Capalbo C. Metodologia das ciências sociais: a fenomenologia de Alfred Schütz. 2 ${ }^{\mathrm{a}}$ Ed. Londrina: UEL; 1998.

50. Merighi MAB. Trajetória profissional das enfermeiras obstétricas egressas da Escola de Enfermagem da Universidade de São Paulo: um enfoque da fenomenologia social. Rev Lat Am Enferm. 2002; 10(5): 644-53.

51. Conselho Nacional de Saúde. Resolução n. 196, de 10 de outubro de 1996. Dispõe sobre diretrizes e normas regulamentadoras de pesquisas envolvendo seres humanos. Bioética. 1996; 4( 2 Supl): 15 25.

52. Morse JM. Determining sample size. Qual Health Res 2000; 10(1): 35. 
53. Holloway I, Wheeler S. Qualitative Research in Nursing. 2nd ed. Oxford: Blackwell Publishing; 2002.

54. Garnica AVM. Educação, matemática, paradigmas, prova rigorosa e formação do professor. In: Coelho IM, Garnica AVM, organizadores. Fenomenologia: uma visão abrangente da educação. São Paulo. Olho D’água; 1999.

55. Schutz A. Estúdios sobre teoria social. Escritos II Buenos Aires (AR): Amorrortu Editores, 2003.

56. Silveira AO; Ângelo M. Interaction experience for families who lives with their child's disease and hospitalization. Rev. Latino-Am. Enfermagem, Ribeirão Preto, v. 14, n. 6, Dec. 2006.

57. Coyne I, Cowley S. Challenging the philosophy of partnership with parents: A grounded theory study. International Journal of Nursing Studies 44 (2007) 893-904.

58. Smykowski L, Rodriguez W. The Post Anesthesia Care Unit Experience. Journal of Nursing Care Quality. Vol. 18, no 1, pp 5-15.

59. Kamerling SN, Lawler LC, Lynch M, Schwartz AJ. Family-Centered Care in the Pediatric Post Anesthesia Care Unit: Changing Practice to Promote Parental Visitation. Journal of PeriAnesthesia Nursing, Vol 23. № 1(February), 2008: pp 5-16.

60. Frost M, Green A, Gance-Cleveland B, Kersten R. Improving FamilyCentered Care Through Research, Journal of Pediatric Nursing (2010) 25,144-147.

61. Micheli AJ, Curran-Campbell S, Connor L. The Evolution of a Surgical Liaison Program in a Children's Hospital. AORN Journal (2010). Vol 92. № 2 .pp 158-168.

62. Piskosz Z. One Pediatric Emergency Department's Successful Approach to Family-Centered Care. Journal of Emergency Nursing. (2007); 33: 169-71.

63. Cooper LG, Gooding JS, Gallagher J, Sternesky L, Ledsky R, Berns SD. Impact of a family-centered care initiative on NICU care, staff and families. Journal of Perinatology (2007) 27; S32-S37.

64. Molina RCM, Marcon SS. Benefícios da permanência de participação da mãe no cuidado ao filho hospitalizado. Revista da Escola de Enfermagem da USP. (2009); 43(4): 856-64.

65. Rossato-Abéde LM, Angelo M. Crenças determinantes da intenção da enfermeira acerca da presença dos pais em unidades neonatais de alto-risco. Rev Latino-am Enfermagem (2002) janeiro-fevereiro; $10(1): 48-54$. 
66. Paliadelis $P$, Cruickshank $M$, Wainohu D, Winskill R, Stevens $H$. Implementing family-centred care: an exploration of the beliefs and practices of paediatric nurses. Australian Journal of Advanced Nursing. (2005) Volume 23 Number 1. pp 31-36.

67. Fisher C, Lindhorst H, Matthews T, Munroe DJ, Paulin D, Scott D. Nursing staff attitudes and behaviours regarding family presence in the hospital setting. J Adv Nurs. 2008 Dec;64(6):615-24.

68. Rossi CS, Rodrigues BMRD. O típico da ação do profissional de enfermagem quanto ao cuidado familial da criança hospitalizada. Acta Paul Enferm (2010); 23(5): 640-5.

69. Higman W, Shaw K. Nurses' understanding about the delivery of family centred care in the neonatal unit Journal of Neonatal Nursing (2008) 14,193e198.

70. Hopia H, Paavilainen E, Astedt-Kurki P. Promoting health for families of children with chronic conditions. J Adv Nurs. 2004 Dec; 48(6):57583.

71. Conz CA, Merighi MAB, Jesus MCP. Promoção de vínculo afetivo na Unidade de terapia Intensiva Neonatal: um desafio para as enfermeiras. Revista da Escola de Enfermagem da USP. (2009); 43(4): 849-55.

72. Pimenta EAG, Collet N. Dimensão cuidadora da enfermagem e da família na assistência à criança hospitalizada: concepções da enfermagem. Revista da Escola de Enfermagem da USP. (2009); 43(3): 622-9.

73. Barbosa ECV, Rodrigues BMRD. Humanização nas relações com a família: um desafio para a enfermagem em UTI Pediátrica. Acta Scientiarum Health Sciences. (2004). 26(1): 205-12.

74. Wright LM, Bell JM. Retrospective-- Nurses, Families, and Illness: A New Combination Journal of Family Nursing2004 10: 3. DOI: $10.1177 / 1074840703261066$. 
ANEXOS

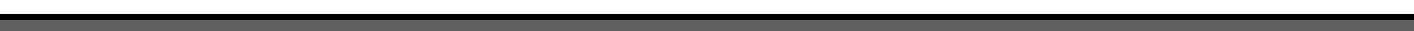




\section{ANEXOS}

\section{ANEXO 1 \\ COMISSÃO DE ÉTICA EM PESQUISA}

São Paulo, 5 de março de 2010.

$I l^{m o(a)} . S^{r(a)}$.

Profa. Dra. Margareth Angelo

Departamento de Enfermagem Materno Infantil e Psiquiatria

Escola de Enfermagem

UNIVERSIDADE DE SÃO PAULO

REFERENTE: Projeto de Pesquisa "Cuidado da família em pediatria: vivência do enfermeiro" - Pesquisador(a) Responsável: Profa. Dra. Margareth Angelo - CoInvestigador(es): Patricia Stella Silva Sampaio - Registro CEP-HU/USP: 979/10 SISNEP CAAE: 0006.0.198.196-10

Prezado(a) Senhor(a)

O Comitê de Ética em Pesquisa do Hospital Universitário da Universidade de São Paulo, em reunião ordinária realizada no dia 5 de março de 2010, analisou o Projeto de Pesquisa acima citado, considerando-o como APROVADO, bem como o seu Termo de Consentimento Livre e Esclarecido.

Lembramos que cabe ao pesquisador elaborar e apresentar a este Comitê, relatórios anuais (parciais ou final, em função da duração da pesquisa), de acordo com a Resolução n 196/96 do Conselho Nacional de Saúde, inciso IX.2, letra "c".

O primeiro relatório está previsto para 5 de março de 2011.

Atenciosamente,

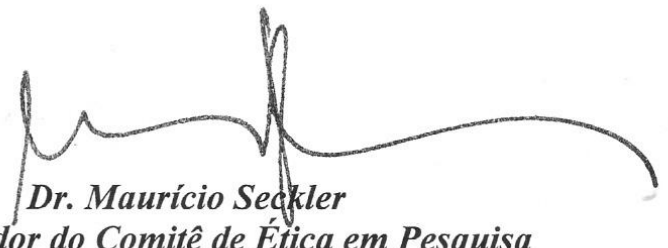

Coordenador do Comitê de Ética em Pesquisa

Hospital Universitário da USP 


\section{ANEXO 2 \\ TERMO DE CONSENTIMENTO LIVRE E ESCLARECIDO}

Prezado(a) Senhor(a):

Meu nome é Patrícia Stella silva Sampaio, sou enfermeira, aluna de Pós Graduação em Enfermagem da Universidade de São Paulo. Estou realizando uma pesquisa que tem por objetivo compreender como os enfermeiros pediatras realizam a abordagem centrada na família.

Havendo concordância em participar deste estudo, comprometo-me a respeitar todos os seus direitos como:

- Ter liberdade de participar ou deixar de participar do estudo, sem que isso Ihe traga algum prejuízo. Este estudo não tem vinculo com o hospital;

- Manter seu nome em sigilo absoluto;

- Interromper a entrevista, caso sinta-se incomodado (a) em continuá-la;

- Realizar as entrevistas em local, data e hora que lhe for mais conveniente;

- Garantir-lhe o direito de resposta a alguma dúvida, durante ou após a sua contribuição com a minha pesquisa.

Deixo-Ihe os telefones: (11) 3368-3726 / (11) 6597-7039 e (11) 3061-7548 (Comitê de Ética em Pesquisa da Escola de Enfermagem da USP), para que possa obter mais esclarecimentos e informações sobre o estudo e sua participação.

Caso aceite participar, farei algumas perguntas, sendo o conteúdo da nossa conversa gravado para posterior transcrição e análise dos dados. As fitas, com os conteúdos das entrevistas permanecerão guardados com a pesquisadora, e somente esta e a orientadora do estudo terão acesso a seu conteúdo. Serão feitas duas cópias: uma ficará comigo (pesquisadora), outra será sua.

Esta pesquisa será publicada em revistas da área de saúde e apresentada em congressos, objetivando a contribuição para um melhor cuidado de enfermagem.

$\mathrm{Eu}$, após ter lido e compreendido as informações acima, concordo em participar como sujeito da pesquisa. Estou ciente dos meus direitos relacionados acima e dou fé que estes princípios serão respeitados pela pesquisadora.

São Paulo, de de 2010. 